\title{
TURKEY AND THE EU: \\ POLITICS AND ECONOMICS OF ACCESSION
}

\author{
HARRY FLAM \\ CESIFo WORKING PAPER NO. 893 \\ CATEGORY 1: Public FinANCE \\ MARCH 2003 \\ An electronic version of the paper may be downloaded \\ - from the SSRN website: $\quad$ www.SSRN.com \\ - from the CESifo website: www.CESifo.de
}




\title{
TURKEY AND THE EU: POLITICS AND ECONOMICS OF ACCESSION
}

\begin{abstract}
This paper discusses political and economic aspects of Turkish accession. Under present rules, Turkey would have the greatest number of council votes within twenty years, and receive the largest budget transfer. Free migration may increase the Turkish immigrant population in Germany from 2 to 3.5 million in thirty years. Most of the economic effects will be felt by Turkey, particularly in agriculture. The main obstacles to accession are not economic, but political. Historical experience prevents Turkey from eliminating the decisive political role of the military, giving Kurds and other minorities cultural rights and upholding basic human rights.
\end{abstract}

JEL Code: F17, F22, H23.

\author{
Harry Flam \\ Institute for International Economic Studies \\ Stockholm University \\ SE-10691 Stockholm \\ Sweden \\ harry.flam@iies.su.se
}

Part of this work was done in cooperation with Subidey Togan, Bilkent University, Ankara, but the responsibility for the contents is solely mine. I am grateful to him and to Refik Erzan for comments without implication. Excellent research assistance was provided by José Mauricio Prado Jr. and excellent editing by Christina Lönnblad. 


\section{Introduction}

Turkish accession to the EU is again making headlines in mass media. The EU has decided to accept the three Baltic countries, five Central and Eastern European countries, Cyprus and Malta as members in 2004. It has also set a timetable for the accession of Bulgaria and Romania, but Turkey has not been given a timetable, despite its status as candidate for membership. The official reason given in the latest Progress Report prepared by the European Commission (2002) is that Turkey does not fulfill the political and human rights criteria for membership as laid down by the European Council in Copenhagen in 1993. Unofficially, the resistance to Turkish accession is also based on fears of large scale immigration and the argument that Turkey is not European: Islam is the predominant religion and most of the population and territory - except a few per cent - are located in Asia.

This paper tries to answer the following questions: Which are the most important economic aspects of Turkish accession to the EU? How important are these for Turkey and the EU respectively? Which are the political obstacles to accession? Are they more important than the economic obstacles?

\section{A short history of EU-Turkish relations}

Turkey applied for associate membership of the EU - the EEC at that time - already in 1959. The application resulted in an Association Agreement in 1963 whereby Turkey and the EU would conditionally and gradually create a customs union by 1995 at the latest. The customs union was considered as a step towards full membership at an unspecified future date. The EU unilaterally granted Turkey financial assistance and preferential tariffs in a first stage, but the second stage of gradual, mutual reductions in tariffs and non-tariff barriers was delayed due to economic and political conditions in Turkey in the 1970 's and the early 1980's. 
Turkey applied for full membership in 1987. The response in 1989 was that the major ongoing changes in the EU and the transition of Eastern Europe and the Soviet Union made it impossible to undertake accession negotiations at that time. However, new efforts were made to realize the customs union, which were actually successful. It was gradually introduced during the period 1996-2001 and trade in industrial goods between Turkey and the EU is now free from tariffs and quantitative restrictions. Turkey has proceeded to align its trade policies with the EU vis-à-vis third countries, granting preferential tariffs to countries in Central and Eastern Europe, the Middle East and North Africa and the signatories of the Lomé Convention, and has adopted technical and administrative aspects of EU trade policy. The customs union is only one part of the Single Market, however. Turkey still has a considerable way to go before it has established conditions for the free movement of services, including rights of establishment, agricultural products, capital and labor. It has made progress in the areas of common standards, the protection of intellectual and industrial property rights and competition rules, agricultural policy and financial regulation.

When a time table for enlargement took shape in the late 1990's, it became difficult to keep the Turkish application on hold. A breakthrough came at the Helsinki meeting of the European Council in 1999, when Turkey attained the status of candidate for membership. It now has a so-called Accession Partnership with the EU, which means that the EU is cooperating with Turkey to enable it to adopt the acquis communitaire, the legal framework of the EU. However, in contrast to other countries, Turkey has not received a time table for accession. The revision of the number of votes and their distribution in the Council of Ministers agreed on during the Nice summit in 2000 did not take Turkish membership into account, which effectively meant that the EU-15 did not plan for Turkey to become a member in the foreseeable future.

\section{Democracy, human rights and the role of history}

The main official reason for keeping Turkey out of the EU has been its failure to live up to the political criteria for membership, that is, the democratic and human rights criteria. 
But to understand the Turkish position and the real difficulties facing Turkey in fulfilling the criteria, some knowledge of the historical background is necessary.

\section{The role of history}

The Turkish Republic was established in 1923, after the attempted dissolution of the Ottoman Empire by western powers at the end of World War I, and a war of liberation against Greek occupation. At the height of its power in the $16^{\text {th }}$ century under Süleyman the Great, the Ottoman Empire stretched from present day Algeria in the west to the Persian Gulf in the east, and from Budapest and the Ukraine in the north to Aden in the south. The Ottomans were engaged in the European wars in the $17^{\text {th }}$ century and had lost a large part of their European territories at the end of the century. The $18^{\text {th }}$ century saw constant wars and defeats against an expanding Russian Empire. The Ottoman Empire had become so weakened at the beginning of the $19^{\text {th }}$ century that it earned the epithet "the sick man of Europe". Frequent wars were not the only reason. The population was divided into religious communities with far-reaching autonomy in many respects, the socalled millet system. Ethnic background played a lesser role than religious affiliation and tribal loyalty. However, in the $19^{\text {th }}$ century, the religious communities were redefined into national and geographic terms and now demanded independence. A large number of European nations emerged from the Empire: first Greece, then Romania, Bulgaria, Serbia and Albania. Bosnia-Hercegovina was taken over by the Habsburgs and Cyprus by Great Britain. The last of the North African holdings were lost to Italy at the beginning of the $20^{\text {th }}$ century. The Ottomans participated in World War I on the German side, and the victorious western powers planned the complete dissolution of Turkey as a state at the end of the war.

For Kemal Atatürk, the principal founder of the new Turkish republic, it was of paramount importance that that the history of disintegration would not repeat itself. If the republic were to survive and keep its territorial integrity, it must build on a common nationality, defined foremost by a common language, be secular, become westernized and refrain from expansionism. The common language and secularity would serve to create 
loyalty to the nation and the state, not to ethnic groups and religious communities, and westernization would help the backward young nation obtain strength through development and industrialization. (The Ottomans had instituted westernization projects already in the $18^{\text {th }}$ and $19^{\text {th }}$ centuries, but with limited success.) Turkish security policy is also shaped by Ottoman history. The Ottoman Empire was expansionist and engaged in endless wars. The republic has tried to avoid conflicts with external powers through the balancing of power. The most important element of this strategy has been its NATO membership, whereby it gained western support against the age-old Russian-Soviet threat. Another element is the military cooperation with Israel, serving as a balance against its southern neighbors. (On Turkish foreign policy, see Aydin, 1998.)

Turkey's desire to become an EU member must be seen in light of the principles underlying the Turkish republic and Turkish security policy; it is a logical step along the path laid out by Atatürk. Turkey wants to become a developed, European country and membership will help it achieve this goal. Furthermore, it will help the country maintain security and stability in its relations with its northern, eastern and southern neighbors.

Turkey's elite, that is the military, most political parties, the powerful central bureaucracy and intellectuals, generally embraces the founding principles of the Turkish republic and is consequently strongly in favor of membership. Membership also enjoys wide public support, with opinion polls generally showing 60-70 per cent of those polled in favor of full membership.

\section{Democracy and the role of the military}

In the constitution, the military was given a special role in safeguarding the republic and its founding principles. In practice, although not formally, it has a decisive voice in issues of internal and external security and foreign policy through the national security council, which is composed of representatives from the military and elected politicians, among them the president and the prime minister. The military has temporarily taken over power 
on three occasions since World War II, in 1960, 1971 and 1980, and has toppled one government by issuing an ultimatum, in 1997.

It is clear that the decisive role of the military in internal politics and external relations is inconsistent with democratic principles. The military should be under the control of the parliament and the government. However, that is not how it is seen by the military and a large majority of the Turkish public. The coup in 1960 was precipitated by a request from the political party in power that the military help suppress the opposition party; the ultimatum and the following military takeover in 1971 came after several years of widespread political violence and calls for the military to step in; the coup in 1980 took place in the middle of a severe economic crisis and after political violence that had claimed about 20 lives per day in the streets in 1979 and 1980; the ultimatum in 1997 was aimed at stopping the systematic islamization in the public sector pursued by one of the coalition parties, later outlawed as being unconstitutional. The fact is that the role of the military in Turkish politics is seen in a positive light by large segments of the population and the military is generally held in high regard by most Turks. ${ }^{1}$ It may be speculated that the role of the military as a guarantor of democracy and political stability creates a moral hazard problem of the first order. It allows politicians to act in a less responsible manner, in the knowledge that the military will step in and reestablish stability, law and order if needed.

\section{Minority and human rights}

Minorities have been an extremely sensitive issue since the creation of the republic. Turkey recognized the religious and communal rights of its non-Muslim minorities, Christians and Jews, in the Lausanne Peace Treaty of 1923, but has placed severe restrictions on the training of clergy, religious education and communal property rights. All Muslims - who constitute 98 per cent of the population - are regarded as Turks,

\footnotetext{
${ }^{1}$ Comparing the military interventions in Turkey in 1960, 1971 and 1980, to Latin American interventions, the Turkish political scientist Ziya Önis (1995) writes that “... the underlying motive in each case has been to 're-equilibrate' democracy, as opposed to a desire to assume power for its own sake and on a longer-term basis as a legitimate alternative to civilian rule."
} 
despite their being composed of several different ethnic groups. Most groups are fairly well assimilated, with the important exception of the large Kurdish minority based in the southeast of the country. The Kurdish population is estimated to about 13 million, i.e. roughly 20 per cent of the total population.

Given the history of disintegration of the Empire as a result of emerging nationalism, the ethnic Turkish majority views expressions of Kurdish nationalism as a threat to the territorial integrity of Turkey. It can point to recent decades of armed conflict with Kurdish nationalists that is said to have cost 30000 lives and has forced hundreds of thousands of Kurds from their villages to urban areas in Turkey or abroad. Five and six million Kurds live in bordering parts of Iraq and Iran, respectively, and about one million in northern Syria. Turkey fears that the Kurds will unite and create an independent state. It is telling that the Turkish army keeps a close watch on the presently autonomous northern, Kurdish, part of Iraq, and has sought assurance from the United States that Iraq will not be split up in case of a change of rule.

In order to assimilate various ethnic groups and foster a common Turkish identity, Turkish laws have severely restricted the public use of languages other than Turkish as well as other expressions of separate cultural identity. The use of minority languages in public institutions, notably schools and universities, and mass media has been prohibited. Recently, and under the pressure from the EU, the constitution was changed to allow some public use of minority languages. The most recent Accession Report by the European Commission (2002) reports that Turkish authorities are continuing their repression of the public use of Kurdish, using other laws than those that were changed. There is a clear connection between the severe limitations placed on the exercise of cultural or minority rights and the widespread abuse of human rights by the military, the police, courts and the prison system. An additional problem is that laws are frequently not implemented, or implemented in an inconsistent manner. 
The Copenhagen meeting of the European Council in 1993 set up several criteria for membership in preparation for Eastern enlargement. These can be divided into political, human rights and economic criteria. In terms of political and human rights criteria, membership requires " ... stability of institutions guaranteeing democracy, the rule of law, human rights and respect for and protection of minorities". The European Commission has faulted Turkey for human rights violations and lack of control by elected politicians over the military. In its review in 2002, the Commission notes progress in meeting the political criteria, including changes in the constitution, but finds that the criteria are still not met in such areas as human rights and freedom of expression and association, and that existing laws are often not implemented.

Meeting the economic criteria is not the major problem for Turkish membership. Turkey has recently reformed its legislation and policies in areas such as financial services, telecommunications, electricity generation and distribution, and agriculture to meet the these demands. The major problem lies in meeting the political and human rights criteria. Placing the military under full political control and ridding it of its power in the judicial system would constitute a break with the fundamental principles guiding the Turkish republic and an ideology with deep roots in the Turkish historical experience. The same can be said about recognizing individual and collective cultural rights for minorities, primarily the Kurds, although in this case, the problem seems to be less monumental.

It is quite clear that the EU has been dragging its feet regarding Turkey's application for membership. Unlike the other candidate countries, Turkey seems to have no strong proponent among the EU countries. The EU can point to the fact that Turkey fails to meet the Copenhagen criteria in all areas, but there are also other possible reasons. One reason may be the implications for the EU budget. Turkey's size, its large agricultural sector and low income would make it the largest net recipient from the EU budget. A second reason may be the power Turkey would get in EU decision-making by the sheer size of its population. Turkey may well have a population larger than that of Germany by 2020 if the present population trends continue. A third reason, and probably the most important 
of all, is the fact that Turkey is seen as foreign to Europe, what political scientists call the Other of Europe (Müftüler-Bac, 1998).

The European identity is questioned on the grounds that less than five per cent of Turkey's population and territory are located in geographical Europe, and that Turkey has a different culture. Several public statements have been made by prominent European politicians to object to Turkish membership for these reasons. For example, the former German Chancellor Helmut Schmidt has voiced his objection on religious grounds (Kalaycioglu, 2002). Recently, the present chairman of the European Convention on the Future of Europe and the former president of France, Giscard d'Estaing, said in an interview that he objected to Turkish membership because Turkey had "a different culture, a different approach, a different way of life" and because "its capital is not in Europe, 95 \% of its population is outside Europe, it is not a European country." Admitting Turkey would mean "the end of the European Union", since it would set a precedent for admitting Middle Eastern and North African countries, starting with Morocco. The head of the government of Bavaria in Germany, Edmund Stoiber, has argued that "Europe cannot end on the Turkish-Iraqi border." (International Herald Tribune, November 9, 2002). In response to such sentiments one may add that Europe as a set of values or as a region of shared history has no clear demarcation (Stråth, 1999). As for shared history, the Ottoman Empire certainly was directly involved in the making of war and peace in Europe for centuries.

\section{Some basic descriptive statistics}

Table 1 shows some basic data for the Turkish economy and makes a comparison with other candidate countries and the EU. 
Table 1. Comparison between EU-15, CEEC-10 and Turkey, 2000

\begin{tabular}{|c|c|c|c|c|c|c|c|}
\hline & \multirow[b]{3}{*}{$\begin{array}{l}\text { Population } \\
\text { (million) }\end{array}$} & \multirow{3}{*}{$\begin{array}{l}\text { GNI, PPP, } \\
\text { (Current } \\
\text { billion } \\
\text { euro) }\end{array}$} & \multirow{3}{*}{$\begin{array}{c}\text { Per capita GNI } \\
\text { PPP, } \\
\text { (Current } \\
\text { billion euro) }\end{array}$} & \multicolumn{2}{|c|}{ Agriculture } & \multirow{2}{*}{\multicolumn{2}{|c|}{ Export shares to }} \\
\hline & & & & \multirow{2}{*}{$\begin{array}{l}\text { Value added, } \\
\text { percent of } \\
\text { GDP }\end{array}$} & \multirow{2}{*}{$\begin{array}{c}\text { Employment, } \\
\text { percent of } \\
\text { Total Employment }\end{array}$} & & \\
\hline & & & & & & $\begin{array}{c}\text { Turkey } \\
(\%)\end{array}$ & $\begin{array}{l}\mathrm{EU} \\
(\%)\end{array}$ \\
\hline Bulgaria & 8.2 & 45 & 5,530 & 15.8 & 11.2 & 10.3 & 51.7 \\
\hline Czech Republic & 10.3 & 140 & 13,610 & 3.4 & 5.3 & 0.6 & 68.8 \\
\hline Estonia & 1.4 & 13 & 9,050 & 5.7 & 7.0 & 0.2 & 68.5 \\
\hline Hungary & 10.0 & 121 & 12,060 & 3.9 & 7.2 & 0.7 & 75.2 \\
\hline Latvia & 2.4 & 17 & 6,960 & 3.9 & 14.4 & 0.0 & 64.7 \\
\hline Lithuania & 3.7 & 26 & 6,960 & 2.5 & 18.4 & 1.8 & 47.9 \\
\hline Poland & 38.7 & 349 & 9,030 & 2.9 & 18.7 & 0.4 & 70.1 \\
\hline Romania & 22.4 & 143 & 6,380 & 11.4 & 45.2 & 6.1 & 64.0 \\
\hline Slovak Republic & 5.4 & 59 & 11,000 & 2.7 & 7.5 & 0.4 & 59.1 \\
\hline Slovenia & 2.0 & 35 & 17,390 & 4.3 & 9.6 & 0.8 & 63.9 \\
\hline Total CEEC-10 & 104.5 & 948 & 9,068 & 5.1 & 21.5 & 2.0 & 67.6 \\
\hline Austria & 8.1 & 213 & 26,310 & 1.2 & 6.1 & 0.7 & 61.4 \\
\hline Belgium & 10.3 & 282 & 27,500 & 1.1 & 1.9 & 1.0 & 74.9 \\
\hline Denmark & 5.3 & 145 & 27,120 & 2.0 & 3.7 & 0.4 & 67.3 \\
\hline Finland & 5.2 & 128 & 24,610 & 0.9 & 6.2 & 1.3 & 55.3 \\
\hline France & 58.9 & 1,440 & 24,470 & 2.3 & 4.2 & 1.1 & 61.4 \\
\hline Germany & 82.2 & 2,054 & 25,010 & 0.9 & 2.6 & 1.4 & 56.5 \\
\hline Greece & 10.6 & 179 & 16,940 & 6.8 & 17.0 & 5.1 & 43.6 \\
\hline Ireland & 3.8 & 97 & 25,470 & 2.6 & 7.9 & 0.5 & 60.0 \\
\hline Italy & 57.7 & 1,348 & 23,370 & 2.4 & 5.2 & 1.8 & 54.9 \\
\hline Luxembourg & 0.4 & 20 & 45,420 & 0.6 & 2.4 & 0.5 & 84.0 \\
\hline Netherlands & 15.9 & 417 & 26,170 & 2.2 & 3.3 & 0.8 & 78.8 \\
\hline Portugal & 10.0 & 169 & 16,880 & 2.4 & 12.5 & 0.4 & 79.5 \\
\hline Spain & 39.4 & 757 & 19,180 & 3.7 & 6.9 & 1.7 & 69.1 \\
\hline Sweden & 8.9 & 211 & 23,770 & 0.7 & 2.9 & 1.2 & 55.0 \\
\hline United Kingdom & 59.7 & 1,407 & 23,550 & 0.7 & 1.5 & 1.0 & 56.9 \\
\hline EU-15 & 376.3 & 8,865 & 23,557 & 1.7 & 4.3 & 1.2 & 62.1 \\
\hline Turkey & 65.3 & 459 & 7,030 & 14.2 & 32.7 & - & 52.3 \\
\hline
\end{tabular}

Source: The first three columns are from World Development Indicators Online, World Bank. Agricultural value added and agricultural employment data are from European Commission, Directorate General for Agriculture. Trade data are from IMF, Direction of Trade Statistics CD-ROM. 
The most important fact about Turkey is its size; in terms of population it would be the second largest member of an enlarged EU. Moreover, the demographics are such that Turkey is likely to surpass Germany and become the largest country in about 2020.

Turkey is among the poorest candidate countries, but is not quite as poor as Bulgaria and Romania in terms of PPP-adjusted income per capita. It should be added that the income disparities across Turkey are great, with the population in the southeast having less than half the national average income and the large rural population generally being much poorer than the urban population. Turkey's relatively low level of development appears in the share of the labor force in agriculture and value added. Only Bulgaria and Romania have a similar dependence on agriculture.

In general, Turkey is not an important trading partner of the EU countries and the CEEC10, with the exception of Greece, Bulgaria and Romania. On the other hand, the EU is Turkey's most important trading partner, although Turkey's exports are not as concentrated to the EU as those of the CEEC-10.

The descriptive statistics suggest that the important economic effects of Turkish accession should be related to its size, per capita income, and dependence on agriculture. For the EU, these three factors combine to create a huge immigration potential, if migration is let free. Moreover, they mean that Turkey may become the largest recipient of transfers from the EU budget, at least under present rules and policies. For Turkey, accession may result in important economic effects in the agricultural sector, given its size and the fact that it would have to adjust to the Common Agricultural Policy.

\section{Migration}

The PPP-adjusted income per capita in the EU is more than three times higher than in Turkey; it will probably take decades before Turkey attains an income level comparable to that of the EU-15. The income differential will continue to be a strong incentive for migration from Turkey to the EU. Turkish migration to Western Europe was particularly 
high in the 1960 's, but has remained a steady continuous flow, particularly to Germany and, to a lesser extent, the Netherlands. A period of active recruitment of foreign labor in many of the present EU countries in the 1950's and 1960's ended after the first oil crisis in 1973-74. Since then, immigration policies have become successively more restrictive, and immigrants have mostly consisted of relatives of former immigrants, refugees and asylum seekers. Most migrants from Turkey have ended up in Germany, which has a population of Turkish origin of 2.1 million. The second largest recipient has been the Netherlands, with 250000 immigrants and their descendants from Turkey.

The prospect of large-scale immigration from Turkey and the other candidate countries is a source of considerable concern among the EU-15, where it is feared that the immigrants will depress wages, boost unemployment and cause social frictions and political upheavals. Free migration will surely not be allowed immediately upon full membership. In the case of the CEEC-8 entering in 2004, the present EU members can restrict immigration from the new members for a period of seven years. The same transition period was applied also when Greece, Portugal and Spain joined. One may therefore safely assume that immigration from Turkey will be subject to restrictions for several years.

\section{Migration theory}

The effects of migration from Turkey to any of the EU-15 member states can be illustrated with the help of figure 1. The horizontal axis measures the total supply of labor in Turkey and - say - Germany. At first, I will simplify and assume labor to be a homogeneous factor of production. Later, I will take into account that labor is differentiated by education, training and experience. The demand for labor by employers in Turkey is shown by the demand curve $D^{T}$. Likewise, the demand for labor in Germany is shown by the demand curve $D^{G}$. The total supply of labor in Germany and Turkey is assumed to be fixed. Initially, it is divided so that the supply of labor in Turkey is measured by the length of the line segment $L^{T} L^{0}$ and the supply of labor in Germany by the length of the line segment $L^{G} L^{0}$. The supply of labor in each country is assumed to be 
inelastic. Before migration is allowed, the equilibrium wage in Germany is $w^{G}$, which is much higher than the equilibrium wage in Turkey, $w^{T}$.

\section{Figure 1. Effects of migration}

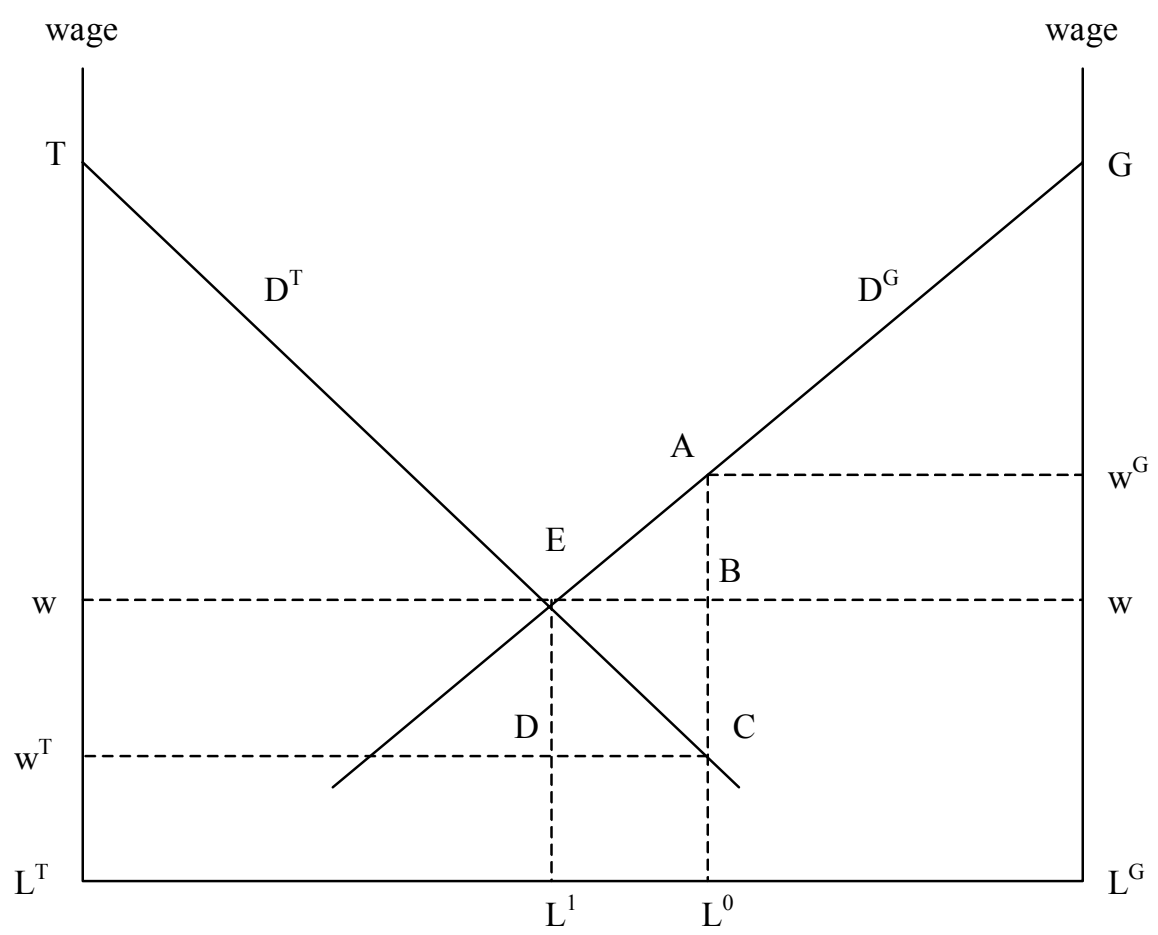

When free migration is allowed, labor will move from Turkey to Germany in order to earn the higher wage. Migration stops when the wage is equalized between the two countries, at $w$, and $L^{1} L^{0}$ of the labor force has moved from Turkey to Germany. Thus, one effect of migration is that it raises the wage in the sending country and reduces the wage in the receiving country. Migrants as well as those remaining in Turkey gain, while German workers lose. The effects for capital owners are the opposite; Turkish capital owners now earn the surplus $T w E$ instead of $T w^{T} C$, while German capital owners earn $G w E$ instead of $G w^{G} A$. (We assume that capital does not migrate in response to earnings differences.) The fact that part of the labor force has moved from Turkey to Germany 
also means a decline in Turkish GDP and a rise in German GDP. All these changes amount to an increase in the combined social surplus or welfare. The increase is given by the area $A C E$ and it is captured by German capital owners and Turkish migrants. The welfare increase is due to a more efficient allocation of labor; Turkish laborers become more efficient when moved to Germany and the optimal allocation is achieved when the marginal productivity of labor in Germany and Turkey is equalized.

Figure 1 provides a simplistic, yet powerful, analysis of the income, redistribution, output and welfare effects of migration. It builds on the assumption that migration is entirely driven by a wage differential and no unemployment exists. Unemployment can easily be added to the model. Assume that before migration is allowed, $L^{l} L^{0}$ of the Turkish labor force is unemployed. Those employed now earn a higher wage, $w$ instead of $w^{T}$. Assume also that employment is decided by a daily lottery. Thus, the expected wage (the actual wage $w$ times the probability of winning employment) is lower than the actual wage and lies somewhere between $w$ and $w^{T}$. The expected wage in Turkey is still below the certain wage $w^{G}$ in Germany, so that labor will migrate to Germany once migration is allowed. Assume that all the unemployed in Turkey migrate to Germany, but that employment will remain unchanged in Germany, despite the inflow of migrants. Employment in Germany is also decided by a daily lottery, where German and Turkish workers have equal probabilities of winning. The expected wage therefore falls below w, ${ }^{\mathrm{G}}$ but not all the way to $w$. Thus, in the new equilibrium, the actual and the expected wage are both higher in Germany than the actual wage in Turkey. The expected wage can be higher in Germany because workers attach a negative value to the risk of becoming unemployed and demand a higher expected wage to compensate for the risk. The analysis here captures the idea first expressed in a model of rural to urban migration in a developing country by Harris and Todaro (1970).

It is seen that Turkish migration can serve both to depress wages in the receiving country and to raise unemployment. Changes in the assumptions made, such as allowing employment to increase in Germany or letting Turkish workers have a higher risk of becoming unemployed, would not change the basic conclusions. One assumption in the analysis is questionable, however, namely that labor is homogeneous. In reality, labor is 
highly differentiated according to education, training, experience and many other characteristics. Thus, there are not only two factors of production, labor and capital, but many types of labor and many types of capital. As soon as three factors or more, are allowed for, the effects of migration on income distribution and social welfare become less clear cut; see Borjas (1995). In general, the effects on native labor and capital become more favorable when immigrants are complements rather than substitutes to the native factors. For example, if the German labor force is skilled and the Turkish immigrants are unskilled, then immigrants tend to increase the productivity and wages of German workers. Likewise, the increase in social surplus from migration tends to rise, the more complementary migrants and native workers are. In terms of figure 1, a smaller substitutability between labor and capital means that the demand curves become steeper and the size of the surplus triangles becomes greater (up to a point).

Naturally, the decision to migrate is not only dependent on relative wages and unemployment, but also on many other factors. The early theoretical research focused on income differentials and individual decisions, as in Berry and Soligo (1969). Recent research stresses that migration is a household decision, and that social networks, culture, language, geographical distance and other factors are also of importance. (For a survey, see Ghatak et. al., 1996.)

\section{Empirical research findings}

Empirical research on immigration has largely focused on two questions (Borjas, 1994). First, how do immigrants perform in the host country? Second, what is the impact on the wages and employment of natives? Most of the research has been done on the United States, and is therefore not fully relevant for Europe. In the past, immigration to the United States has been of a more permanent nature than immigration in Europe, which has an impact on the performance of immigrants. Furthermore, European labor markets are generally considered to be more rigid than those in the United States, due to stronger labor unions, more regulation and immigration policies.

The recent wave of immigration in the United States differs from past waves by the markedly lower level of education of immigrants, compared to natives. Whereas earlier 
immigrants fairly soon reached similar income and employment levels as natives, later immigrants have not. Moreover, there is a high correlation between first and second generation immigrants in terms of educational attainment, and therefore a high probability that also the second generation will fall behind (Borjas, 1994). These findings for the United States may be applicable to Europe and, in particular, to immigration from Turkey, which mostly consists of people from rural areas with low levels of education.

There is little evidence that immigration has a significant negative effect on the employment opportunities of natives, either in the United States or in Europe. There is, however, some evidence of small negative effects on the wage of unskilled labor in both . On the other hand, a positive effect on the wage of skilled labor has been found in Germany, as can be expected when unskilled immigrants are complements to skilled native workers. ${ }^{2}$

A third question that has been the subject of some research and which has received much attention from policy makers and the general public is whether immigrants are net recipients or contributors to the public coffer. The problem with earlier studies is that they focus on a single year, neglecting the cost and expenditures for an immigrant later in life, such as pensions, and that they do not consider some general equilibrium interactions, such as that between immigrants and an aging population. The studies by Auerbach and Oreopoulos (1999) and Storesletten (2000) for the United States take a dynamic, life-cycle approach with partial or general equilibrium interactions. They find negative, but relatively small, fiscal effects of low-skilled immigration. Storesletten estimates the average net present value of a representative low-skilled legal immigrant to be $-\$ 36,000$. A high-skilled immigrant, on the other hand, contributes $\$ 96,000$ over her life-time. A study of Germany by Bonin (2001) finds a significant positive effect of the average immigrant over the life-cycle; a net immigration of 200,000 to Germany is estimated to yield natives 200 euro per capita and year. The positive effect is due to the average immigrant being of younger working age and thus being obliged to participate in

\footnotetext{
${ }^{2}$ For the United States, see Friedberg and Hunt (1995), for Europe, see Zimmerman (1995), for Germany, see Haiskens-De New and Zimmerman (1996) and for Germany and Austria, see Winter-Ebmer and Zimmerman (1998).
} 
the repayment of existing government debt. The fiscal impact of immigration is bound to differ between European countries, depending on the structure and level of taxes and benefits.

The empirical research on the economic effects of immigration to Germany, host to the largest immigrant population among the EU-15 and the largest population of Turkish immigrants by far, seems to indicate fairly small and, on the whole, positive effects; employment opportunities are not much affected, the wage of low skilled labor is somewhat depressed but that of skilled labor is raised, and the net present value of public transfers is positive. It is more difficult to evaluate the social costs and benefits of immigration. There are many examples in urban Europe of failed absorption of immigrants. Immigrant ghettos with high unemployment, criminality and social problems loom large in the minds of the native population in many countries, although the immediate costs are mostly born by the immigrants themselves.

Estimated model of migration to Germany from Southern Europe (Boeri and Brücker, 2000)

We have made a forecast of free Turkish migration to Germany, based on an estimated model of immigration to Germany from the EU-15, Norway, Turkey, the United States and former Yugoslavia by Boeri and Brücker and their co-authors in a report to the European Commission (2000), henceforth BB. The choice of Germany is dictated by the facts, first, that Germany holds the largest population of Turkish immigrants among the EU-15 by far and can therefore be expected to attract the largest numbers of future immigrants and, second, the paucity of data on migration flows and stocks before the 1990 's for most of the EU-15 countries.

BB estimated how the flow of migration depends on the wage differential, employment rates in the home and host countries, the stock of migrants from the home country, restrictions on migration and country specifics, such as language differences, distance and institutions. The migration decision is seen as dependent on expectations about the future wage differential based on present and past values of the differential, conditioned 
by the individual probability of finding employment in the host country, relative to the home country, which is assumed to be based on present and past average employment rates, the ease of adjustment, proxied by the number of migrants in the host country, the difference in development between the home and host country and language differences, and agreements regulating migration, such as guest-worker agreements. Migration flows are seen as short-run adjustments to a long-run equilibrium where migration has ceased and the stock of migrants has attained an equilibrium level dependent on the wage differential, the employment rate differential, restrictions on migration and countryspecific factors. The long-run equilibrium is also estimated, giving long-run relations between the stock of migrants and the explanatory variables. ${ }^{3}$ The existence of a long-run equilibrium builds on the assumption that the propensity to migrate has a certain distribution over individuals in the home country; the equilibrium is reached when those with the highest propensity have emigrated for given long-run values of the explanatory variables and those remaining do not find emigration worthwhile. ${ }^{4}$

BB first estimate a (error-correction) model taking account of migration responses to short-run deviations from long-run equilibrium relations. The signs of the coefficients on the explanatory variables correspond to the signs found in the estimation. The equation was estimated with data on migration to Germany from 18 industrialized countries during the period 1967-1998:

(1) Change in migrant population in the receiving country/population of the sending country $=\beta_{1}$ (country-specific factors) $+\beta_{2}$ (change in GDP per capita in the sending country relative to the receiving country) $+\beta_{3}$ (change in employment in the receiving country) - $\beta_{4}$ (change in employment in the sending country) +

\footnotetext{
${ }^{3}$ Boeri and Brücker estimate an error-correction model. The assumptions and the model are described in detail in Boeri and Brücker (2000).

${ }^{4}$ A common approach to explain migration is to estimate a gravity equation. Yearly migration is explained by wage and employment rate differentials, distance, language, regulation, the stock of earlier migrants in the host country, i.e. much the same variables as in the present error-correction model. A problem with this approach is the long-run implication that the entire population will leave for a sufficiently large income differential. The error-correction model tests for the existence of a long-run equilibrium where only a (small) part of the population has emigrated. Technically, it tests for co-integration between the variables. We have estimated a gravity equation of migration between Germany as the host country and Greece, Portugal and Spain as the home countries with disappointing results; most of the coefficients were
} 
$\beta_{5}$ (GDP per capita in the sending country relative to the receiving country in the previous year) $+\beta_{6}$ (employment in the receiving country in the previous year) - $\beta_{7}$ (employment in the sending country in the previous year) - $\beta_{8}$ (migrant population/population of the sending country in the previous year) $+\beta_{9}$ (dummy variable for free migration) $+\beta_{10}$ (dummy variable for guest worker agreement)

The long-run equilibrium relations between the ratio of the migrant population in the receiving country relative to the population of the sending country on the one hand and the explanatory variables on the other, can be found by setting the changes in equation (1) equal to zero and estimating the resulting equation describing the long-run equilibrium relations:

(2) Migrant population in the receiving country/population of the sending country= $\left(\beta_{1} /-\beta_{8}\right)$ (country-specific factors) $+\left(\beta_{2} /-\beta_{8}\right)$ (GDP per capita in the sending country relative to the receiving country) $+\left(\beta_{6} /-\beta_{8}\right)$ (employment in the receiving country) $-\left(\beta_{7} /-\beta_{8}\right)$ (employment in the sending country) $+\left(\beta_{9} /-\beta_{8}\right)$ (dummy variable for free migration) $+\left(\beta_{10} /-\beta_{8}\right)$ (dummy variable for guest worker agreement)

The signs of the coefficients within parenthesis correspond to the estimated signs. As expected, in the long run, the migrant population in the receiving country is positively related to the income differential between the sending and the receiving country, the employment rate in the receiving country, free migration and guest worker agreements, and is negatively related to the employment rate in the sending country.

\section{Forecast of migration from Turkey to Germany}

We have used the BB estimation of equation (1) to forecast free migration from Turkey to Germany from 2000 to 2030 . To make a forecast, we must make assumptions about population and GDP growth rates and employment rates for the whole period. For 
population growth, we have used the forecasts given by the World Bank in its World Development Indicators database. For GDP, we simply assume a GDP growth rate for Germany equal to the average for 1990-2000. The GDP and population growth rates yield a GDP per capita growth rate of 1.7 per cent. For Turkey, we assume a higher GDP growth rate. We make forecasts based on the assumption that every year, 1, 2 or 3 per cent of the per capita income gap is closed. This means that GDP per capita in Turkey is assumed to grow at (very high) 9, 12 or 15 per cent at the beginning of the period and at about 3 per cent at the end. The average rate is about 5.5 per cent for the 2 per cent assumption. The Turkish GDP and GDP per capita growth rates have been about 5 and 3 per cent, respectively, over the last five decades. Our assumption implies that GDP growth must increase by about 2 percentage points for GDP per capita to grow at 5.5 per cent.

The results of the forecast are shown in figure 2. As can be seen, the Turkish immigrant population starts out at about 2.2 million in 2000 and reaches about 3.5 million in 2030 under the assumption that no restrictions are placed on migration. 
Figure 2. Forecast of the Turkish immigrant population in Germany

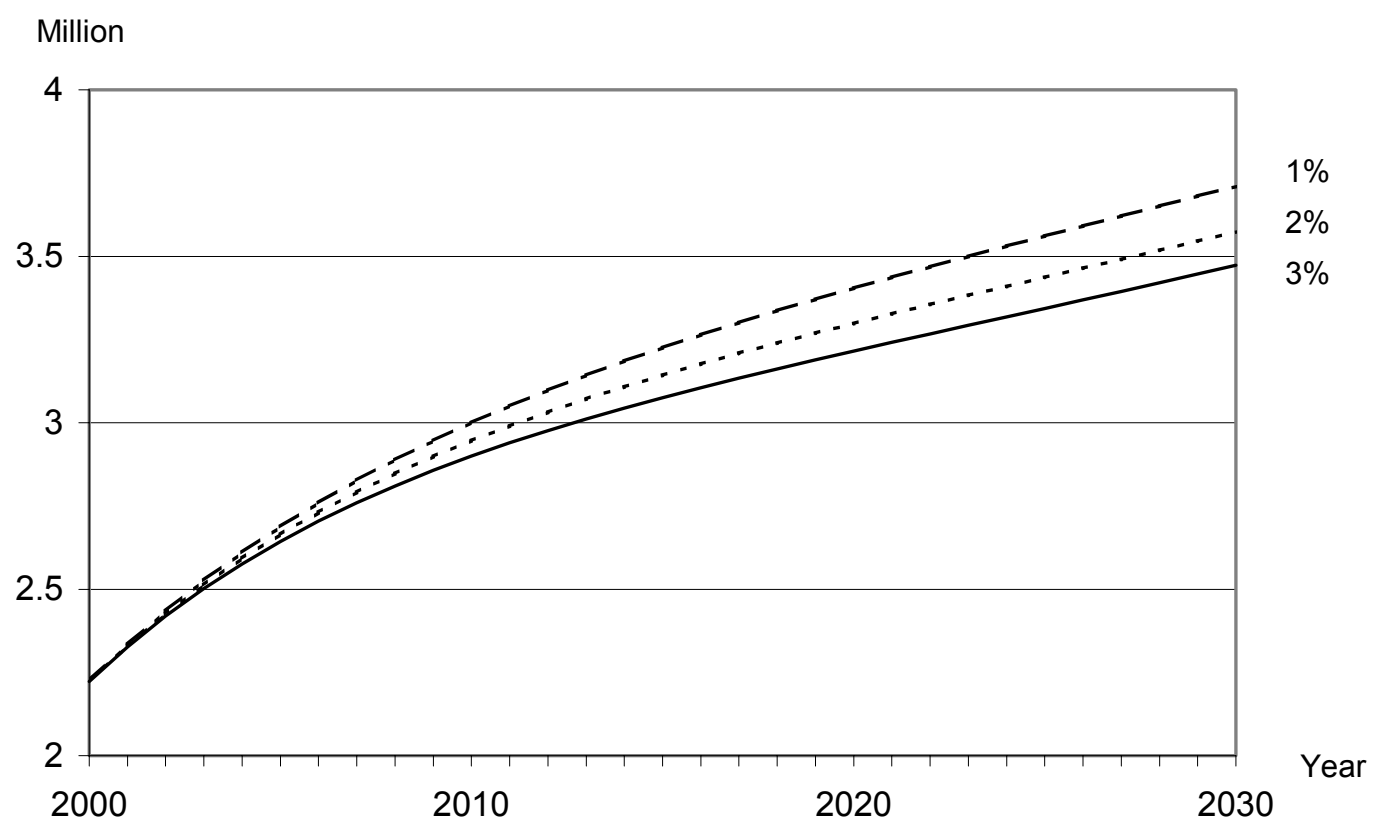

Note: Forecasts for a 1, 2 and $3 \%$ convergence rate of per capita income between Germany and Turkey. Source: Own calculation based on Boeri and Brücker (2000).

It must be stressed that this forecast is highly uncertain. It depends on the specification of the migration model, the estimates of the model which, in themselves, are uncertain, and heroic assumptions about GDP and population growth rates. Furthermore, we assume that estimates made for a group of countries in a certain time period in the past can be applied to a different country pair and a different time period. Finally, the forecast assumes that the Turkish migrant population in Germany is far from its equilibrium value (which is to say that our estimated fixed effects for Turkey in equation (1) are crucial for the forecast).

Ideally, we would like to have forecasts of Turkish migration to all EU-15 countries. Lack of data makes it impossible to estimate an equation such as equation (1) for more than one or two countries. However, Germany is the most important country of immigration from Turkey by far, and it would dominate any estimate of immigration to the whole of EU. 


\section{Agriculture}

Agriculture is an important part of the Turkish economy. Its contribution to GDP is about 14 per cent and its share of employment 33 per cent. The corresponding figures for EU15 are 1.5 and 4.8 per cent, respectively. Turkey employs about the same number of people in agriculture as the EU-15 but the size of its area of cultivation is only one third .

Until recently, agricultural support has placed a large burden on Turkish taxpayers. Transfers to farmers have amounted to about 5 per cent of GDP and the total support to agriculture, including the higher prices paid by consumers, has been estimated at 8 per cent of GDP. The share of agriculture in GDP and employment and the extent of transfers to agriculture indicate that accession can have important social, distributional and political effects in Turkey. Accession means that Turkey would have to adopt the Common Agricultural Policy and would receive agricultural subsidies. At the same time, the size of the Turkish agricultural sector threatens to be costly for EU taxpayers if Turkish farmers are to have the same terms as the farmers of the CCEC-8. The latter will receive 25 per cent of the full level of income support when they join in 2004, to be increased by 5 percentage points in 2005 and 2006, when the present EU budget period ends. The Commission has proposed that direct payments continue to be gradually increased so that the new members reach the full level in 2013. However, it is unlikely that the CAP will remain unchanged in view of the increased financial burden enlargement would entail.

\section{Turkish agricultural policy}

Turkey is in the process of abandoning its system of input subsidies and output price supports in favor of a system of direct income support, as in the Common Agricultural Policy (CAP) of the EU. If the reforms are fully implemented, the consequences will potentially be great for Turkish farmers, at least in the absence of compensating CAP financing. Until now, Turkish policy has consisted of guaranteed output prices, input subsidies, some limited control of supply, free or low cost services to farmers, import protection and export subsidies. The CAP is moving towards world market prices and 
maintaining farmers' incomes through direct payments tied to acreage and livestock holdings instead of guaranteeing high prices for agricultural products.

Price support has been the most important part of Turkish agricultural policy. State economic enterprises and agricultural sales cooperatives have been commissioned to buy cereals, tobacco, tea and sugar beet from farmers at prices determined by the government. These higher than world market prices have been protected by import tariffs. The second most important component of the policy has consisted of various subsidies, grants and exemptions with the purpose of reducing the cost of inputs, including capital, fertilizer, seed, pesticides and water. The output of tobacco, hazelnuts, tea and sugar beet has been controlled in various ways. Services to farmers, e.g. research, training, extension and inspection services were provided free or at a low cost.

Turkey has granted very few preferential tariffs on agricultural imports from the EU. On the other hand, the EU has granted imports from Turkey a highly preferential treatment. A considerable part of the agricultural imports enters the EU without duties. Import barriers mostly exist in the form of tariff-quota schemes, where imports within the quota are free from tariffs, and an entry price scheme, where specific duties are applied if the value of the consignment falls below the entry price. It is estimated that about 70 per cent of the imports from Turkey enter the EU duty free and without any other import barriers. However, high specific duties are applied to the core products of the CAP: cereals and processed cereals, sugar and sugar products, dairy products and meat. Olive oil is also highly protected. Turkish exports of vegetables and fruits receive export subsidies.

The present agricultural reforms in Turkey are a result of the Uruguay Round agreement on agricultural trade and Turkey's own efforts to adjust to the CAP. The reforms are also, to some extent, prompted by an agreement with the IMF in 1999 to reform agricultural policy - that is, to make it less costly - as a condition for IMF support. Under the reform program, output price supports and input subsidies and grants in various forms will be phased out and replaced by direct payments to farmers based on land holding, and tariffs will gradually be reduced. Income support is capped at 20 hectares and it is estimated that the total support will cost in excess of 2 billion euros. The reforms are being implemented 
at present and are planned to be completed in two years time. Privatization of state enterprises in the agricultural sector is also part of the program.

If the reforms are brought to completion, Turkey will have an agricultural policy similar to the CAP; high intervention prices and protection from the world market have been replaced by direct income support, lower protection and prices approaching world market prices. Implementing the program requires extensive administrative reforms. For example, substantial investments are needed in improving land registration, collecting agricultural data, and raising the veterinary and plant sanitary standards.

\section{Effects of policy changes}

The present agricultural policy reform of the EU covers the period 2000-2006, while the implementation of the Turkish program started in 2000 . We can safely assume that the date for Turkish accession lies beyond 2006 and presume that both sets of reforms will have been implemented at the time of accession. The consequences for the EU of admitting Turkey are mainly related to financing the CAP and rural development in general.

For Turkey, the benchmark is different. The Turkish reforms can be seen as a consequence of accession (as well as the need to reduce public expenditure). In the short run, they will lead to a substantial reduction in farmers' incomes. Lower administered prices and the elimination of input subsidies are far from compensated by direct income support. It is estimated that the total support - measured per hectare of land under cultivation - will decline from USD 295 per hectare to USD 68, including direct income supports (averages for 1997-99; OECD, 2000). Although this represents a large reduction, it is fairly small in relation to total farm income. In terms of the value of agricultural output, the total support was estimated at 13 per cent in 2000, which should be compared to the EU average of 38 per cent in 2000 (OECD, 2001). The present price reductions in Turkey will not reduce prices to the new CAP levels. Disregarding any direct income compensations, the adoption of the CAP would therefore lead to further income reductions. However, we also need to consider CAP subsidies to Turkish farmers. These subsidies are largely, but not entirely, independent of the income level of the 
recipient country. If Turkey were to fully benefit from CAP subsidies, its farmers would be able to raise their income above the level after the present reforms given that the total support per hectare is much higher in the EU, or an annual average of USD 845 in 199799 (60 per cent of which consist of transfers from taxpayers; OECD, 2000). In other words, accession is likely to provide a gain for Turkish farmers, certainly in relation to the situation after the present reforms and probably also the situation before the reforms.

The consequences for agricultural production and trade of adopting the CAP, including free trade with the EU, are less clear. The fact that prices in Turkey are generally higher than in the EU indicates that agricultural production will contract and the trade position with the EU deteriorate. Turkey had a agricultural trade surplus of about EUR 1.3 billion with the EU in 1999. Most of this was in fruits, vegetables and tobacco, which can already enter the EU practically free of charge. The effects of a customs union in agricultural products between the EU and Turkey will therefore be small for Turkey's main export items. Vegetables, fruits and tobacco have a higher tariff protection from third countries in Turkey than in the EU; adopting the EU tariff rates may therefore induce some competition from imports.

\section{The EU budgetary effects of accepting Turkey today ${ }^{5}$}

The structure of the present system of EU revenue and expenditure is such that rich member states transfer resources to poor members, but the relation between income per capita and net transfer is far from straightforward. Some rich countries give proportionately more than others, while some poor countries receive a disproportionate share of the transfer. Turkey and the CEEC-10 are all poor relative to the EU 15. Much attention has therefore been given to the budgetary effects for the EU of enlargement on the assumption that it will be very costly for the EU 15. The present net recipients from the EU budget have feared that they will be the ones to bear a disproportionate share of the cost and the net contributors that they will be required to raise their contributions.

\footnotetext{
${ }^{5}$ This section draws on the corresponding discussion in Baldwin et al (1997).
} 
The major items on the revenue and expenditure sides of the budget in 2002 are shown in table 2.

Table 2. The EU budget in 2002

\begin{tabular}{|c|c|c|c|c|c|}
\hline & \multicolumn{2}{|c|}{ Revenues } & & \multicolumn{2}{|c|}{ Expenditure } \\
\hline & Million euro & Share & & Million euro & Share \\
\hline Duties and levies & 15267 & 17.3 & Agriculture & 40506 & 48.6 \\
\hline VAT & 35193 & 40.0 & Structural Operations & 27591 & 33.1 \\
\hline GNP & 37580 & 42.7 & Internal policies & 5361 & 6.4 \\
\hline Correction* & -71 & & External expenditure & 5231 & 6.3 \\
\hline Total & 87969 & 100.0 & Administrative & & \\
\hline Other revenue** & 4755 & & expenditure & 4643 & 5.6 \\
\hline Total & 92724 & & Total & 83331 & 100.0 \\
\hline
\end{tabular}

Notes: *Does not add to zero due to exchange rate differences. **Interest, surplus from previous years, fines, taxes on salaries of employees of European institutions, etc.

Source: European Commission, Allocation of 2000 EU operating expenditure by Member State, tables $5 \mathrm{a}$ and $\mathrm{b}$.

Revenues are collected from three sources: member states' VAT revenues, customs duties collected by member states and a tax related to member states' GNP. The total contribution to the EU budget is, by decision, capped at an annual amount equal to 1.27 per cent of GNP until 2006, when the present long-term budget ends.

Expenditures have two main destinations: the CAP and the so-called Structural Operations aimed at disadvantaged countries and regions. Until recently, the CAP has built on price supports. Prices on many agricultural products are kept above world market prices by the buying up of excess supplies at administratively determined minimum prices and by protecting EU markets from low world market prices by duties on imports. Excess supplies are disposed of at a loss in the EU and on the world market. Starting in 1993, the CAP has gradually shifted away from price to income support. Prices in the EU are reduced towards world market prices and farmers are compensated by direct income payments, based on their holdings of land and animals. The CAP favors farmers and the 
main agricultural products of the original EU-6, namely grains, sugar beet, dairy products and beef. Fruits, vegetables, poultry and pork, important products of the newer, southern members, receive less or no support.

Structural Operations are based on criteria of underdevelopment and structural disadvantages of particular regions and countries. Regional support is given by the socalled Structural Funds. For example, to be eligible for support under the classification of Objective 1, a region must have a per capita income of less than 75 per cent of the EU average. About 55 per cent of the Structural Operations expenditure fall under this classification. By construction, the Cohesion Fund is exclusively directed at Greece, Ireland, Portugal and Spain. Cohesion Fund expenditure is modest, or about 2 per cent of the total budget, but it is important for the recipient countries.

One way of calculating Turkey's contributions to and receipts from the EU budget would be to estimate the "tax base", i.e. VAT and tariff revenue and GNP, and the extent to which Turkish agriculture and regions are eligible for support from the CAP, Structural Funds and the Cohesion Fund. The calculation is likely to come up with a large net transfer to Turkey, both because of the size of the agricultural sector and because Turkey is poor relative to the EU-15. We find it unlikely that the EU-15 will accept Turkey as a member if this proves to be very costly. Turkish accession will come after the accession of the CEEC-10, Cyprus and Malta. These countries are also poor - with the exception of Cyprus - and have relatively large agricultural sectors. When the EU-15 determine new rules for contributions to and receipts from the budget, they will consider the budgetary effects of a future EU-28. Since the EU-15 will be relatively large net contributors after enlargement under the present rules, they will, we argue, want to change the rules in order to reduce the amount of redistribution from rich to poor member states. Their ability to do so before the enlargement is actually considerable. The question is what will happen once the enlargement has taken place?

The history of past enlargements shows that rules are changed if an acceding country becomes a disproportionately large net contributor or is a disadvantaged recipient of CAP or Structural Funds support under the existing rules. The United Kingdom has a relatively 
small agricultural sector and receives modest CAP support. After a long struggle, it won a permanent rebate - a "correction of budgetary imbalances" - on its contribution. Portugal and Spain also receive modest CAP funding since their agriculture produces relatively little grains. After their accession, it was decided to limit the aggregate CAP spending in favor of Structural Funds spending, which benefited Portugal and Spain. The Cohesion Fund set up in 1993 - ostensibly to help the poor members cope with EMU - can also be seen as a compensation to Greece, Ireland, Portugal and Spain. Austria, Finland and Sweden do not have poor regions eligible for much support from Structural Funds. Objective 6 (later included in Objective 1) was created as a compensation.

The rules for contributions to and receipts from the EU budget favor poor countries, since contributions are more or less proportional to income per capita, while Structural Operations are targeted at poor countries and regions to raise their income relative to richer countries and regions. CAP has a bias towards temperate climates and therefore, the richer members, but not enough to overturn the re-distributive effects of Structural Operations. In the final instance, the rules in a future EU-28 will depend on the voting power of the new members and the voting rules.

The present rules give small countries more voting power per capita than large countries. Consider the extremes: Germany with a population of 83 million has 10 votes in the Council of Ministers while Luxembourg with a population of 400000 has 2, giving voters in Luxembourg 42 times the voting power of voters in Germany. Most of the candidate countries are relatively small. The largest are Turkey, with 65 million, Poland, 38 million, and Romania, 23 million. Overall, poor countries will have more votes in the EU-28 than in the EU-15. At present, there are 87 votes in the Council. Under the existing rules, decisions must be either unanimous or made with a qualified majority of 62 votes, or 71 per cent. Under the new rules agreed on at the European Council meeting in Nice, 74 per cent of the votes will be required for a qualified majority, starting in 2005. The 13 candidate countries would add as many as 53 votes to the Council, based on the present allocation of votes according to population size. ${ }^{6}$ Turkey should receive 10 votes,

\footnotetext{
${ }^{6}$ The Nice Treaty set the number of votes in the Council to 348, once the EU-27 has been established. The new distribution of votes per member state is more differentiated with respect to population size than the
} 
the same number as France, Germany, Italy and the United Kingdom each. Thus, a coalition of poor, new member states can easily block decision-making in the EU-28.

Voting power should therefore be a good indicator of how much a country receives from the EU in the form of CAP and Structural Operations support. The history of enlargement has shown that if new members feel disadvantaged under the existing rules, they will change the rules and eligibility criteria to achieve a more favorable outcome. At the same time, GNP per capita is a good indicator of how much a country has to contribute to the EU budget. An alternative way of calculating the budgetary effects for new members is therefore to estimate the contribution per capita in the EU-15 based on income per capita, and estimate the receipts per capita based on per capita Council votes and the level of development in a broader sense, as indicated by eligibility for Cohesion Fund status. ${ }^{7}$ The results of such an estimation are shown in table 3.

\section{Table 3. Estimates of contributions/receipts equations}

\begin{tabular}{lcc}
\hline \hline & $\begin{array}{c}\text { Receipts } \\
\text { per capita }\end{array}$ & $\begin{array}{c}\text { Contributions per } \\
\text { capita }\end{array}$ \\
\hline GNP per capita & & 0.008 \\
& & $(0.00)$ \\
Votes per capita & 19.3 & \\
& $(0.067)$ & \\
Cohesion dummy* & 629.9 & \\
& $(0.00)$ & 0.78 \\
Adj. $\mathrm{R}^{2}$ & 0.86 & 15 \\
No. obs. & 30 & \\
\hline
\end{tabular}

Notes: P-values in parenthesis. Receipts per capita on data for 1999 and 2000, contributions per capita on data for 2000 . *Interacted with votes per capita.

Source: European Commission, Allocation of 2000 EU operating expenditure by Member State, various tables, 2001.

present distribution, but the voting power distribution is still very regressive, with Malta receiving 22 times more voting power per citizen than Germany.

${ }^{7}$ This approach was taken in Baldwin et al (1997). 
As can be seen, GNP per capita alone can explain 78 per cent of the variation in contributions per capita among the EU-15. The estimated effect is highly significant. As for receipts per capita, the number of votes per capita and Cohesion Fund status can explain as much as 86 per cent of the variation in the data. The effect of voting power is borderline significant (it is significant at the 10 per cent but not at the 5 per cent confidence level), while the effect of Cohesion Status is highly significant.

The estimates of table 3 were then used to estimate the contributions and receipts of each of the candidate countries. It must be remembered that these estimates are based on the present distribution of votes among the EU-15 and the present rules for contributions and receipts.

Table 4. Estimated contributions and receipts for candidate countries

\begin{tabular}{|c|c|c|c|c|c|c|c|c|}
\hline & $\begin{array}{l}\text { Population } \\
\text { million }\end{array}$ & $\begin{array}{c}\text { GDP } \\
\text { million } \\
\text { euro }\end{array}$ & $\begin{array}{c}\text { Assumed } \\
\text { votes }\end{array}$ & $\begin{array}{c}\text { Cohesion } \\
\text { status }\end{array}$ & $\begin{array}{c}\text { Contribution } \\
\text { per capita, } \\
\text { euro }\end{array}$ & $\begin{array}{c}\text { Total } \\
\text { contribution, } \\
\text { million euro }\end{array}$ & $\begin{array}{c}\text { Receipts } \\
\text { per capita, } \\
\text { euro }\end{array}$ & $\begin{array}{c}\text { Total } \\
\text { receipts, } \\
\text { million euro }\end{array}$ \\
\hline Poland & 38.7 & 174 & 8 & 1 & 90 & 3472 & 297 & 11505 \\
\hline Romania & 22.4 & 39 & 6 & 1 & 67 & 1499 & 337 & 7544 \\
\hline Czech Republic & 10.3 & 55 & 5 & 1 & 96 & 992 & 477 & 4917 \\
\hline Hungary & 10.0 & 49 & 5 & 1 & 93 & 930 & 487 & 4868 \\
\hline Bulgaria & 8.2 & 13 & 4 & 1 & 65 & 536 & 479 & 3927 \\
\hline Slovak Republic & 5.4 & 21 & 3 & 1 & 84 & 453 & 523 & 2823 \\
\hline Lithuania & 3.7 & 12 & 3 & 1 & 79 & 293 & 688 & 2544 \\
\hline Latvia & 2.4 & 8 & 3 & 1 & 79 & 190 & 971 & 2331 \\
\hline Slovenia & 2.0 & 19 & 3 & 1 & 133 & 266 & 1133 & 2266 \\
\hline Estonia & 1.4 & 5 & 3 & 1 & 84 & 118 & 1548 & 2168 \\
\hline Cyprus & 0.8 & 10 & 2 & 0 & 159 & 128 & 212 & 170 \\
\hline Malta & 0.4 & 4 & 2 & 1 & 133 & 53 & 3394 & 1358 \\
\hline Turkey & 65.3 & 215 & 10 & 1 & 80 & 5200 & 263 & 17152 \\
\hline Total & & & & & & 14130 & & 63572 \\
\hline
\end{tabular}

Source: World Bank, World Development Report, 2001 and own estimates. 
The total net transfer to the 13 countries is quite large, 49 billion euro, which is equivalent to more than half of the present budget of the EU-15. Turkey would receive a net transfer of about 10 billion euro, and Poland a net of about 8 billion. The smaller countries receive net transfers that are much larger per capita than the larger countries, due to their greater voting power. The extreme cases are Malta and Turkey, with net transfers of 3400 and 263 euro per capita, respectively. The distribution of votes that we have assumed is, of course, somewhat uncertain, as is the assumed eligibility for Cohesion Fund support. We have assumed that all countries except Cyprus qualify because their per capita income would be less than 75 per cent of the EU-28 average. A less generous assignment of Cohesion Fund status would generate substantially lower net transfers.

It is clear that the accession of all candidate countries requires substantial changes in the EU budget. There are numerous alternatives. The gross contribution should be increased to allow much larger net transfers between Member States. Another alternative is to drastically reduce the amount of redistribution, which must be achieved by a reduction in Structural Operations, since these are re-distributive to a greater extent than CAP financing.

It seems clear that accepting the CEEC-10, Malta, Cyprus and Turkey will be costly for the EU-15 countries. In particular, some countries that are now net recipients may become net contributors. Is that acceptable to them? Such prospects might explain the less than enthusiastic endorsement of enlargement among the recipient countries of Cohesion Fund financing, in particular Greece, Portugal and Spain.

\section{The trade potential}

Turkey was a fairly closed economy until the early 1980's. At that time, and as part of more wide-ranging economic reforms, the policy of protection and import substitution was replaced by a much more open trade regime. The result was a rapid increase in trade; the ratio of the average of exports and imports to GDP increased from 0.09 in 1980 to 
0.25 by 1999 . Turkey's pattern of trade in goods is shown in table 5 .

Table 5. Turkey's commodity trade pattern, 1999

\begin{tabular}{|c|c|c|c|c|}
\hline & \multicolumn{4}{|c|}{ Percent } \\
\hline & $\begin{array}{c}\text { Export } \\
\text { share }\end{array}$ & $\begin{array}{c}\text { Share of } \\
\text { exports to } \\
\text { EU }\end{array}$ & $\begin{array}{l}\text { Import } \\
\text { share }\end{array}$ & $\begin{array}{l}\text { Share of } \\
\text { imports } \\
\text { from EU }\end{array}$ \\
\hline Agricultural products & 17 & 14 & 9 & 5 \\
\hline Food & 16 & 13 & 5 & 2 \\
\hline Agricultural raw materials & 1 & 1 & 4 & 3 \\
\hline Mining products & 4 & 4 & 17 & 4 \\
\hline Ores and other minerals & 2 & 2 & 2 & 1 \\
\hline Fuels & 1 & 1 & 13 & 2 \\
\hline Non-ferrous metals & 1 & 1 & 2 & 1 \\
\hline Manufactures & 79 & 82 & 74 & 91 \\
\hline Iron and steel & 6 & 4 & 4 & 3 \\
\hline Chemicals & 4 & 2 & 15 & 19 \\
\hline Other semi-manufactures & 8 & 7 & 5 & 7 \\
\hline Machinery and transport equipment & 19 & 21 & 38 & 50 \\
\hline Textiles & 13 & 13 & 5 & 4 \\
\hline Clothing & 25 & 32 & 1 & 1 \\
\hline Other consumer goods & 4 & 3 & 6 & 7 \\
\hline Total value, million euro & 28847 & 15568 & 44145 & 23236 \\
\hline
\end{tabular}

Source: Calculations by S. Togan

There is a striking deficit in the balance of trade in goods of 14 billion dollars overall and 7 billion with the EU. However, the numbers in table 5 do not include substantial transit and shuttle trade. Shuttle trade includes trade carried out by people from parts of the former Soviet Union, who travel to Turkey to fill large suitcases with various goods to bring back. The transit and shuttle trade is estimated to generate 3-4 billion dollars in net exports. The deficit in goods trade is also balanced by a surplus in tourism services. In fact, tourism is the single largest export item, with export revenues of about 7 billion in 1999. 
Table 5 shows that Turkey has a comparative advantage in agricultural goods, primarily fruits and vegetables, iron, steel, textiles and clothing, that is, in resource and labor intensive goods, and a comparative disadvantage in physical and human capital intensive goods, as revealed by large net imports of more sophisticated manufactures.

When considering whether full membership is likely to change the pattern and volume of trade between the EU-15 and Turkey, it is important to keep in mind that the customs union in industrial goods was established in 1996, and that a period of at least ten years of free trade would precede full membership. The difference between a customs union in industrial goods and being part of the Single Market is free trade in agricultural goods and services, and free mobility of capital and labor - after some transitional period. Thus, no significant effects of membership on the trade pattern in industrial goods should be expected. Trade in agricultural goods will be affected, but the major effects will be in Turkey, not in the EU-15, since the import barriers are already relatively low for Turkish agricultural exports.

For some decades to come, Turkey's comparative advantage will be in low-skill, low wage activities in manufacturing. Compared to the CEEC-10, Turkey is probably significantly less endowed with human capital because of a generally much lower level of secondary and higher education. The average level of schooling for an adult is 4-5 years. Only recently did Turkey raise the mandatory minimum length of schooling from five to eight years.

Although the pattern of Turkish - EU trade is not expected to change substantially as a result of full membership, there is considerable potential for an increase in the volume of trade. The CEEC-10 have experienced substantial increases in trade volumes as a result of large investments by firms from Western Europe and elsewhere, which combine their technical, managerial and marketing assets with a generally well-educated and skilled labor force at low wages. Turkey has a long way to go before it can hope to attract foreign direct investment to the same extent as some of the more successful countries in Central and Eastern Europe. For example, Turkey attracted 15 dollars in foreign direct investment per capita in 2000 compared to 256 dollars in the case of Poland, the most 
successful of the CEEC. Foreign direct investment in Turkey is hampered by political uncertainty, bureaucracy, detailed regulation and - by rumor - corruption. Turkey has one of the lowest rankings in terms of foreign direct investment potential and performance according to UNCTAD (2002). Membership and adoption of the acquis will go some way towards establishing a better investment climate which, in turn, should lead to higher volumes of trade in the same way as for the CEEC-10.

We have made a forecast of the volume of trade between Turkey and the EU-15 under the assumption that trade will reach the same level of intensity as trade between the EU member states at present. The forecast is based on estimations of a so-called gravity equation for trade within the EU-15. The gravity equation has been used to explain the bilateral trade volume since the 1960's, and has proven to be remarkably successful. It postulates that the volume of trade between a pair of countries is typically a function of the size of the trade partners, measured by GDP, population or geographic area, their income levels or capital abundance, measured by GDP per capita, and of trade costs, measured by a variety of factors, such as tariffs and other administratively imposed trade barriers, geographic distance, common borders, common language or common legal systems. ${ }^{8}$

We have estimated the following standard version of the gravity equation:

$\log [($ exports from country $i$ to country $j+$ exports from country $j$ to country $i) / 2]=$ $=$ constant $+\beta_{1} \log ($ GDP of country $i x$ GDP of country $j)+\beta_{2} \log$ (GDP per capita in country $i x$ GDP per capita in country $j$ )

$+\beta_{3} \log$ geographical distance + dummy for common land border + error term

\footnotetext{
${ }^{8}$ Standard versions of the gravity equation can be derived from all three basic trade models, i.e. the Ricardian, Heckscher-Ohlin and increasing returns to scale models, as well as from other models, as demonstrated by Anderson (1979), Bergstrand (1990), Deardorff (1998), and Helpman (1998). Recent research has sought to ascertain to what extent the various models contribute to the empirical success of the gravity equation and thereby to evaluate their empirical relevance, see Feenstra, Markusen and Rose (1999) and Evenett and Keller (2002). A tentative conclusion is that models based on increasing returns and product differentiation are more successful in explaining intra-industry trade, while trade in homogeneous goods is better explained by differences in factor endowment or differentiation of goods by country of origin (Armington assumption).
} 
The dependent variable in the gravity equation is the logarithmic average of bilateral exports. It is explained by the logarithmic product of GDP; the volume of trade is simply assumed to rise in proportion to the combined economic size of the trade partners. GDP per capita can be considered as a measure of product differentiation and specialization. The higher the per capita income is, the more differentiated are taste and production, and the larger is the volume of trade based on product differentiation and increasing returns to scale. A high per capita income is also an indication of abundance of physical and human capital relative to manual labor. Thus, the per capita variable should serve to capture both intra-industry trade caused by product differentiation and increasing returns to scale, and inter-industry trade caused by differences in factor endowments. Trade costs are controlled for by the inclusion of geographical distance and a common land border. Geographical distance is an indicator of transportation costs, but also of the costs of cultural differences which tend to increase with geographic distance. Finally, a common land border is considered to have a level effect on the volume of trade.

The estimates of the gravity equation are presented in table 6. Two estimation methods were used, OLS and random-effects GLS, which yield similar estimates. The gravity equation explains more than 90 per cent of the variation in the data. All coefficients are estimated with a very high level of statistical significance (less than $1 \%$ ) and have the expected sign, with one exception. The product of real per capita GDP is found to have an unexpected, negative effect on the volume of trade, when distance is controlled for. However, the coefficient changes signs and becomes positive and highly significant when distance is omitted from the regression, as in the second column. Clearly, the results indicate the income differentials between present EU members and distance to be positively correlated (the correlation between the log of the product of per capital GDP and distance is - 0.51). 
Table 6. Pooled panel gravity estimates for intra-EU-15 trade

\begin{tabular}{lccc}
\hline \hline & OLS (1) & OLS (2) & Random-effects GLS \\
\hline Log real product GDP & 0.8577 & 0.8818 & 0.8031 \\
& $(0.0098)$ & $(0.0120)$ & $(0.0266)$ \\
Log real product GDP per & -0.2802 & 0.2439 & -0.3722 \\
capita & $(0.0362)$ & $(0.0384)$ & $(0.0342)$ \\
Log distance & -0.8819 & - & -0.9374 \\
& $(0.0326)$ & - & $0.0948)$ \\
Common border & 0.4000 & 1.2557 & 0.4174 \\
& $(0.0516)$ & $(0.0673)$ & $0.1780)$ \\
$\mathrm{R}^{2}:$ Within & - & - & 0.3897 \\
$\mathrm{R}^{2}:$ Between & - & - & 0.9275 \\
$\mathrm{R}^{2}$ Overall & 0.9249 & 0.8797 & \\
& & & \\
\hline
\end{tabular}

Notes: GDP and Population data from OECD Economic Outlook No.70 (Dec. 2001). Trade data from OECD Monthly Statistics of International Trade CD-ROM (June 2001) and great circle distances between capitals from the website http://www.wcrl.ars.usda.gov/cec/java/lat-long.htm. 1155 observations, annual data for 15 countries, 1990-2000. Intercept and year controls not recorded. Standard errors within parenthesis. All estimates significant at less than $1 \%$.

The OLS estimates of the gravity equation in the first column were then used to make forecasts of the bilateral trade of each of the CEEC-10 and Turkey with the EU-15. The results are presented in table 7. As can be seen, the forecasted value of Turkish - EU-15 trade is 26.1 billion dollars in 2000, which is almost fifty per cent higher than the actual value of 18 billion. Most of the CEEC-10 are also projected to increase their trade with the EU-15, some of them considerably more than Turkey, while two countries - Estonia and Hungary - actually have higher actual than projected trade. Note, however, that the point estimates obtained with our forecast method are highly uncertain as shown by the 95 per cent confidence intervals for the point estimates. 
Table 7. Forecast of trade with EU-15

\begin{tabular}{|c|c|c|c|c|}
\hline \multirow[b]{2}{*}{ Country } & \multicolumn{3}{|c|}{$95 \%$ conf. interval } & \multirow[b]{2}{*}{$\begin{array}{l}\text { Forecast/Actual trade, } \\
2000\end{array}$} \\
\hline & $\begin{array}{l}\text { Forecast, million } \\
\quad \text { euro, } 2000\end{array}$ & $\begin{array}{l}\text { Lower } \\
\text { bound }\end{array}$ & $\begin{array}{l}\text { Upper } \\
\text { bound }\end{array}$ & \\
\hline Bulgaria & 4.4 & 1.6 & 12.3 & 1.82 \\
\hline Czech Republic & 24.4 & 9.0 & 65.3 & 1.29 \\
\hline Estonia & 1.8 & 0.7 & 5.1 & 0.69 \\
\hline Hungary & 15.0 & 5.5 & 40.4 & 0.80 \\
\hline Lithuania & 3.5 & 1.3 & 9.4 & 1.82 \\
\hline Latvia & 2.5 & 1.0 & 6.7 & 1.59 \\
\hline Poland & 42.0 & 15.6 & 112.8 & 1.75 \\
\hline Romania & 10.4 & 3.9 & 28.4 & 1.63 \\
\hline Slovak Republic & 11.1 & 4.1 & 30.4 & 2.02 \\
\hline Slovenia & 7.3 & 2.7 & 19.5 & 1.26 \\
\hline Turkey & 28.3 & 10.5 & 76.3 & 1.46 \\
\hline
\end{tabular}

Source: GDP and population data from World Development Indicators On-line (World Bank). Trade data from OECD Monthly Statistics of International Trade CD-ROM (June 2001) and great circle distances between capitals from the website http://www.wcrl.ars.usda.gov/cec/java/lat-long.htm

\section{Macroeconomic instability}

Macroeconomic developments in Turkey since the 1950's are characterized by booms and busts: periods of high growth are interrupted by periods of balance of payments crisis, high inflation, low or negative growth, and political unrest. Nevertheless, the average rate of growth has been quite high, 5-6 per cent. The latest economic crisis, which erupted in 1999, has forced the government to embark on a number of reforms that were, in part, conditions for IMF support and in part prompted by Turkey's new status as a candidate for membership in the EU. Greater macroeconomic stability and lower inflation must be achieved for Turkey to meet the Copenhagen economic criteria.

A brief look at Turkish macroeconomic history in the past 50 years helps us understand the recent crisis and reforms. ${ }^{9}$ In the 1950 's, state economic enterprises had a fifty per

\footnotetext{
${ }^{9}$ The following account for the period 1950-1987 is largely taken from Önis and Riedel (1993).
} 
cent share of the value-added in manufacturing, a virtual monopoly in other sectors and they were the instruments through which the government supported agriculture. State economic enterprises could borrow directly from the Central Bank. Increased demand for credit led to a rapid appreciation of the currency, almost squeezing exports to extinction. At the same time, imports were reduced to a minimum by import quotas. The government was forced to adopt a stabilization program in 1958, including devaluation and fiscal consolidation. The program gave rise to public unrest, and a military government seized power in 1960. The military regime had a strong belief in central planning of the economy and amended the constitution to include a state planning organization. It also embarked on a policy of import substitution. The 1960's were economically successful, with a stable growth rate and only 5 per cent inflation. However, the rate of inflation was sufficiently high to cause a steady appreciation of the exchange rate, which finally forced the government to devalue by 66 per cent in 1970. This caused political unrest and violence, and the military - which is charged with guarding national stability in the constitution - again forced the civilian government to resign. Spurred by easy foreign credit and large remittances from workers abroad, the economy grew at a rapid pace during much of the 1970's. But by 1977, the foreign banks had become worried about the rapidly growing foreign debt and stopped lending. Aggregate growth ceased and industrial production contracted during the next three years, while inflation accelerated. The 1970's was a period of great political instability in Turkey, with a succession of civilian governments and finally, a new a military takeover in 1980. The military government implemented a stabilization and reform program, including a 70 per cent devaluation, anti-inflationary measures, and less emphasis on state enterprises. It managed to stabilize public finances, reduce inflation from more than 100 to about 30 per cent and revive economic growth. The perhaps most important economic achievements were a switch from the protectionist, import-substitution policy towards much liberalized trade and steps to deregulate and privatize. In the 1990's, Turkey developed serious problems in its public finances, which caused a crisis, fiscal stabilization and negative growth in 1994. However, the public finances deteriorated and a new fiscal crisis emerged already in 1998-99, when the IMF was called in and a program of fiscal stabilization and structural reforms was introduced. The new program seemed to be going 
well when a banking crisis erupted in late 2000 and again at the beginning of 2001 . The crisis years of 1994, 1999 and 2001 are characterized by a sizable fall in GDP in the order of 6 per cent, while growth in the interceding years has reached up to 8 per cent. Devastating earthquakes made the fiscal and economic crisis in 1999 worse.

It is clear that the Turkish macro economy has been quite unstable in the past, and that most of the shocks have been domestic. But has the macroeconomic instability been worse than that of some present EU countries? We have compared the business cycle of Turkey, as measured by monthly data on industrial production, with those of Greece, Portugal and Spain. The upward trend in the data has been eliminated by statistical techniques to bring out the variations more clearly. We have also made a comparison with the common component of the business cycles of the EU-9 countries, and of Canada, Japan and the United States, respectively. ${ }^{10}$ The comparison with the regional business cycles may give us some idea of whether the business cycles of the four individual countries have been driven by external business cycles. ${ }^{11}$ The estimation is done for a sufficiently long time period to allow us to investigate whether accession changed the pattern observed for Greece, Portugal and Spain. It is sometimes argued that the close economic integration afforded by EU membership makes the business cycles of new entrants more synchronized, see e.g. Frenkel and Rose (1997).

\footnotetext{
${ }^{10}$ We have used a method suggested by Lumsdaine and Prasad (1999) and also used by Bergman (2000, 2001). One advantage of this method is that the decomposition between a country-specific and a common business cycle component is independent of underlying assumptions about the relation between the components. Moreover, the weights assigned to different countries when calculating the common component can vary over time. Other methods require identifying restrictions or assumptions about the behavior of the common component, see Bergman (2000).

${ }^{11}$ A number of studies of macroeconomic symmetry in Europe have identified a core with a fairly large degree of symmetry consisting of Austria, Belgium, Denmark, France, Germany, Luxembourg and Netherlands. For the rest of the EU-9, Ireland and the United Kingdom are usually found to be quite asymmetric, while Italy falls in between. See the references in Bergman (2000).
} 
Figure 3. Business cycles, 1978-1998
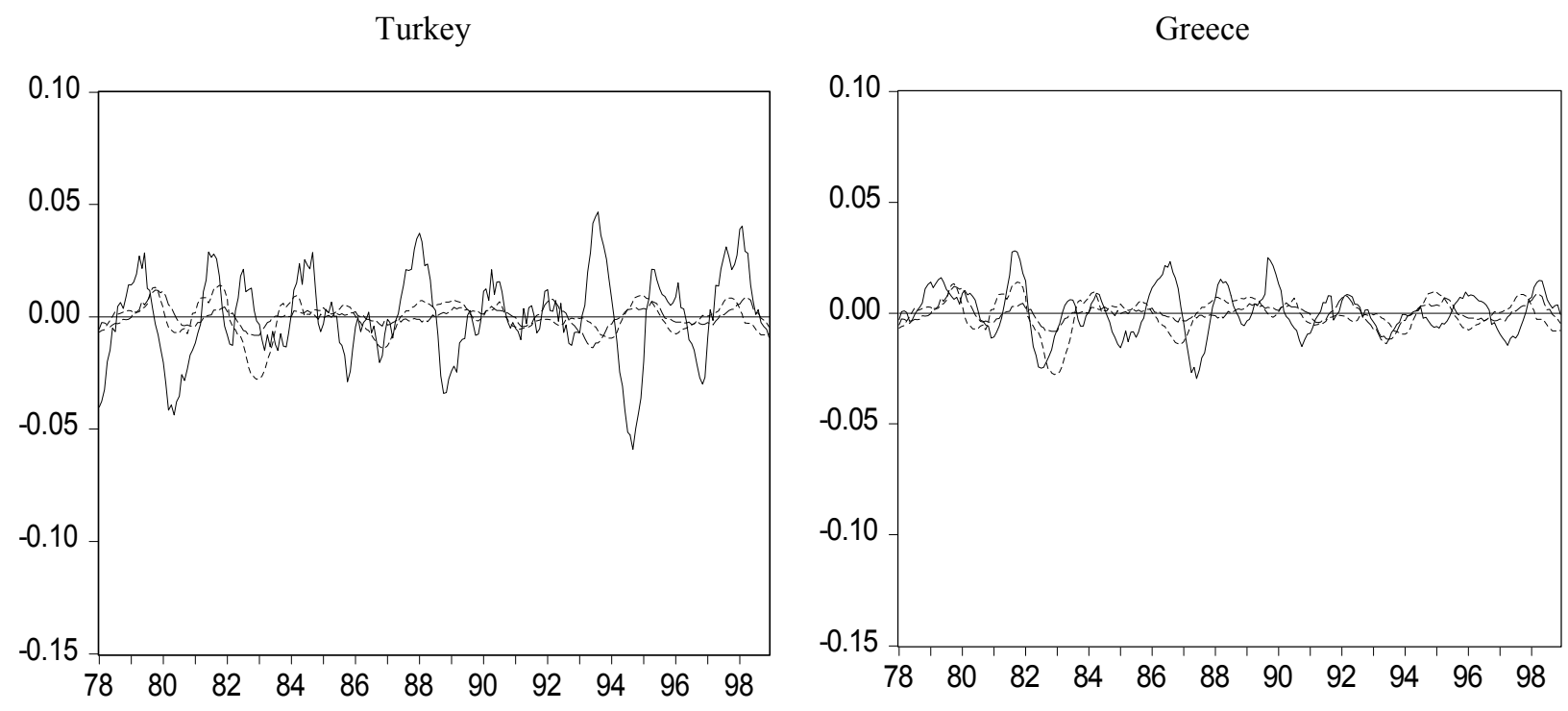

Portugal
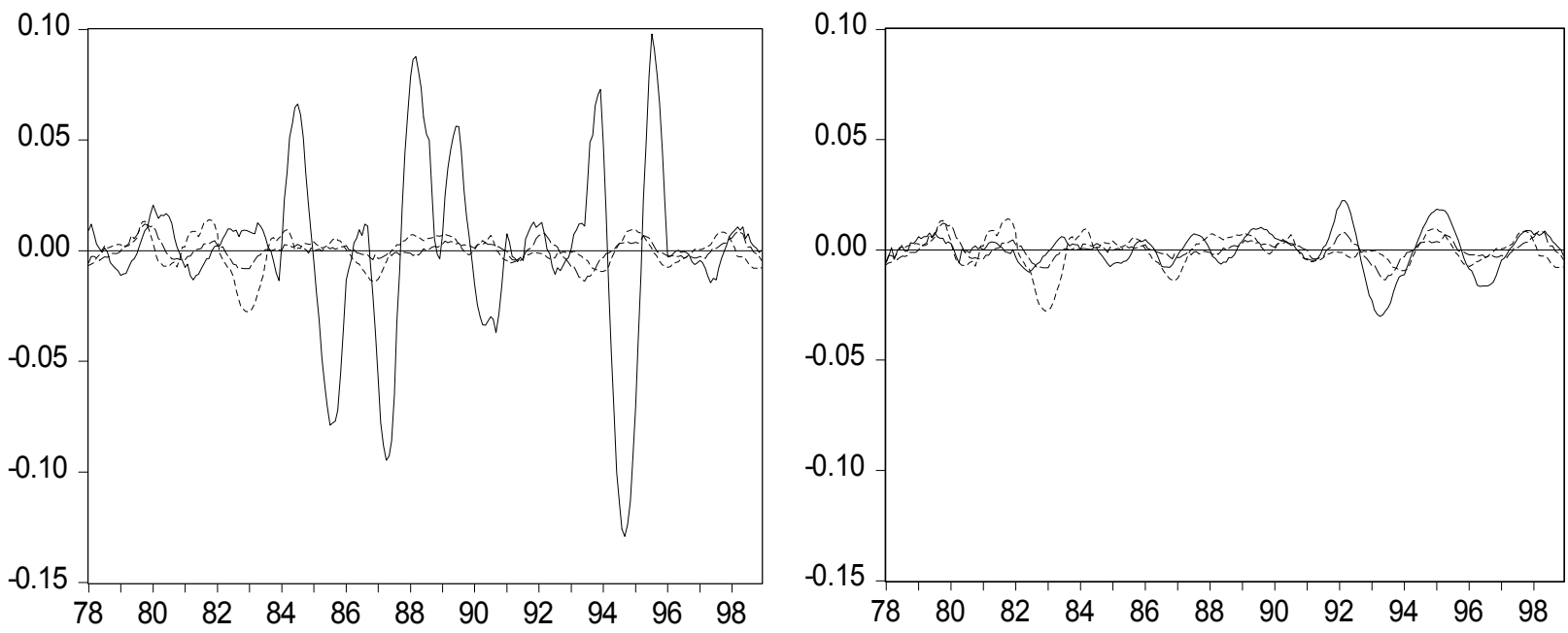

$\longrightarrow$ Country $i \quad----$ Canada + Japan + U.S. $\quad---\cdot$ EU

Note: De-trended time series.

Sources: IMF, OECD (Portugal) and Turkish statistical office 
The panels in figure 3 show the fluctuations in industrial production for Turkey, Greece, Portugal and Spain, together with the common component of the corresponding fluctuations in EU-9 and Canada-Japan-United States. ${ }^{12}$ Several features are noteworthy. First, we cannot see that the volatility of the cycle has decreased after accession in 1986 in the cases of Portugal and Spain, whereas a dampening can be seen for Greece. Second, Portugal and Greece display much greater volatility than Turkey and, in particular, Spain. Third, the Spanish cycle is synchronized with that of EU-9 and Canada-Japan-United States, especially during the 1990's, while the cycles of the other countries are not. It seems that the Turkish business cycle is both volatile and asymmetric with respect to the international economy - as could be expected, given its relatively small degree of openness - but it is not more volatile than the Portuguese cycle and does not seem more asymmetric than the Greek and Portuguese cycles. ${ }^{13} 14$

\section{The political economy of public finances}

Will Turkey continue to experience periodic macroeconomic crises, as in the past, and will inflation remain high, around 75 per cent on average for 1990-2000? The reasons for the recurring macroeconomic problems and the high inflation can be found in heavy state intervention in the economy, the way in which public finances are managed and the parliamentary situation. The present reforms are aimed at the first two factors. There are reasons to believe that they will be much more successful than similar attempts in the past, both because they are wider in scope and structural in character and because

\footnotetext{
${ }^{12}$ The data have been run through a statistical filter to extract the fluctuations from the trend increase in industrial production. The particular filtering method is due to Baxter and King (1999) and we have used a program supplied by Marianne Baxter on her homepage.

${ }^{13}$ It must be noted that the Turkish data on industrial production are reputed to be somewhat unreliable. Nevertheless, they were used, since the statistical techniques require longer time series than those provided by the alternative of quarterly GDP data.

${ }^{14}$ With statistical techniques, we have also investigated the degree of causality between the international business cycles and the business cycles of Turkey, Greece, Portugal and Spain, and whether accession has served to increase the synchronization between the business cycles of the latter three and international business cycles, particularly that of the EU-9. The statistical results were on the whole negative, with low
} 
external constraints are more binding than in the past. Also, the general elections in 2002 gave one party a sizable majority in parliament; the past has seen a long succession of coalition or minority governments.

As already mentioned, state intervention has been pervasive in the economy since the 1930 's. State owned enterprises have been important in a wide range of sectors, such as banking, electricity, paper, steel, coal, railroads, cement, tobacco, textiles and telecommunications. The government has also set up state enterprises to service the agricultural sector with various inputs and to buy up agricultural products at administered prices. Privatization was part of the reform agenda of liberalization and market orientation 1980, but until recently, the record has been dismal. In 1999, there were 49 non-financial state enterprises with about 430000 employees.

Public finance management has had peculiar features in Turkey. As late as in 1999, a substantial part of the activities of the public sector were carried out by semi-autonomous entities called budgetary funds and extra-budgetary funds. The activities of the funds could be divided into four categories: 1) public consumption and investment, 2) price regulation and control, 3) transfers, such as subsidies and social security, and 4) insurance and miscellaneous activities. ${ }^{15}$ In 1999, there were 83 different funds or fund-like institutions. All but five had been closed down at the end of 2001.The funds received their financing from the government budget, taxes and user charges, but they were also used to raise tax revenue for the central government budget. The degree of autonomy of the funds varied, but to some extent, they were free from central government control, especially on the expenditure side.

In addition to the funds, there were other entities that could override central government control, such as state economic enterprises, revolving funds, local administrations, and social security institutions. Sak (2000) refers to an estimate that all arrangements overriding central control reached 30 per cent of total public sector expenditures.

$\mathrm{R}^{2}$ 's and insignificant or small coefficients. The exception is Spain, the business cycle of which is well explained by that of the EU-9, particularly in the 1990's.

${ }^{15}$ This categorization was made by Sak (2000), who gives a detailed account of the workings of the fund system. 
The fund system goes back to the 1930's, but started to be exploited in earnest in the 1980 's. It seems to have been a response to increasing needs for public services and to effect structural change. The regular public finance system was not used for this purpose, due to the legal, bureaucratic and political difficulties in raising taxes and redirecting public expenditures to new areas according to Sak (2000). The system got somewhat out of hand in the 1990's, because of the parliamentary situation. The 1990's saw a succession of coalition and minority governments, where the political parties exploited the fund system, state banks and other state enterprises to favor their voters and enhance their own power. Thus, the problems of public finance in Turkey in the 1990's, which culminated in the crisis in 1999-2001, were due to a combination of political competition and the availability of public funds without sufficient control. The political parties were not punished in elections, presumably because the system was not transparent and because various interest groups had a perception of being favored.

The public sector ran a deficit equal to 24 per cent of GDP in 1999 according to the IMF accounting. The Turkish treasury figure is lower, since it does not include the borrowing made necessary by the operations of state banks.

The reforms started in 1999 are clearly focused on structural problems, in addition to fiscal stabilization. They involve closing down most of the funds, the privatization of state enterprises and a wide-ranging reform and privatization of the Turkish financial sector that will bring regulations and supervision up to EU standards.

It remains to be seen to what extent the whole reform package will be enacted and implemented. The history of stabilization programs and structural reforms in Turkey tells us that some measure of skepticism is in place. Reforms have been implemented only partially, and laws and regulations have been overlooked.

Naturally, the soft budget constraints and the heavy involvement of politicians in the economy are not an accident. By handing out economic favors, politicians and political parties have been able to favor their constituents and secure political power, which 
seems to be an accepted part of Turkish politics. ${ }^{16}$ Once established, such a state of affairs is hard to escape, since it requires that all political parties commit to move to another state, where their power over the state budget has been curtailed. The incentive to defect is potentially great, since economic favors will have more leverage in the absence of competition from other political parties.

One way of moving to a better state of affairs is to seem to be forced by an outside power. The role of the IMF and the EU can be seen in this light. Many of the measures undertaken as a condition for IMF loans and EU membership are, of course, not popular with politicians, interest groups and voters in general. But since they seem to be imposed by outside powers for ends that most recognize as necessary - in the case of IMF assistance - or desirable - in the case of EU membership - they can be accepted. In this respect, it is also helpful that fiscal stabilization and structural reforms are a package where the net outcome for a particular agent is less clear than in the case of isolated changes in policy.

Another external constraint that must be mentioned is the private foreign debt. Prior to the latest crises and depreciation of the currency, the private sector had a very small amount of foreign assets and thus, devaluations did not cause any adverse wealth effects, only favorable competitiveness effects. After the deregulation of capital movements in 1989 , the private sector has accumulated a sizable stock of foreign assets and has suffered capital losses during the latest crisis. This will be remembered by voters in the future, and is likely to act as a new constraint on future governments in their handling of public finances.

\footnotetext{
${ }^{16}$ In fact, in her seminal paper on the phenomenon of rent-seeking, the most frequently cited economics paper of the 1970's, Anne Krueger (1973) was, to some extent, inspired by her studies of the Turkish economy, as shown by examples in the paper.
} 


\section{Conclusion}

We have tried to identify and assess the most important political and economic issues for Turkey's accession to the EU. There are also several important issues that were not mentioned, one of which is the cost for Turkey of adopting the environmental standards as required by the acquis. This cost is likely to be very large. For example, most cities have no or very rudimentary facilities for sewage treatment. Another issue is corruption. There is plenty of anecdotal evidence that corruption is pervasive and deep-rooted in the public sector, see Senatalar (2002) for some evidence. Presumably, to qualify for membership, Turkey will have to demonstrate that it has taken steps to prevent corruption and that these are being successfully implemented.

One conclusion is that Turkey seems to be able and willing to meet the economic criteria for membership. In recent years - albeit under the pressure of an extreme economic crisis and as conditions for IMF and World Bank loans - it has instituted a great number of reforms in many areas: agriculture, the public sector, the financial sector, the state enterprise sector, and so on. It remains to be seen to what extent and at what speed these will be implemented.

Turkish membership is not expected to cause significant effects for the present EU members, except perhaps the budgetary consequences. Turkey has a large population, a low level of income and a large agricultural sector. All these factors combine to make Turkey the largest net benefactor of agricultural and regional subsidies under the present rules. In fact, we estimated that Turkey would receive 12 billion euro net, which corresponds to about 14 per cent of the EU budget. (The overall net contribution to the CEEC-10 and Turkey was projected to correspond to about 60 per cent of the present budget.) For Turkey, the effects will be felt in the whole economy. However, many reforms are already under way to meet IMF and World Bank conditions. Most importantly, income support will be substituted for price support in agriculture, affecting the third of the population that is dependent on agriculture for its living. The public sector, the state enterprise sector and the financial sector are also undergoing reforms. Turkey still has some way to go before it qualifies for participation in the Single Market. 
Trade in industrial commodities is free from tariffs, but many trade barriers in the form of administrative procedures, protection of property rights, technical standards and so on remain to be tackled. Only when foreign direct investment flows to Turkey to the same extent as to the more successful CEECs can we be certain that the reforms have been successfully implemented.

The main obstacle to Turkish accession is in meeting the political criteria. Turkey needs to make the military subordinate to its elected political bodies, extend cultural rights to Kurds and other minorities, and uphold human rights. Whether Turkey will be able to achieve this is in doubt, since it is perceived as a threat to the principles on which modern Turkey was built and therefore, to the unity and integrity of the country. 


\section{References}

Anderson, J. (1979), "A theoretical foundation for the gravity equation," American Economic Review 69, 106-116.

Auerbach, A. and Oreopoulos, P. (1999), "Analyzing the fiscal impact of U.S. immigration," AER Papers and Proceedings 89, 176-180.

Aydin, M. (1998), Determinants of Turkish foreign policy: Historical framework and traditional inputs, Middle Eastern Studies 35, 152-186.

Baldwin, R., Francois, J. and Portes, R. (1997), The costs and benefits of eastern enlargement: the impact on the EU and central Europe, Economic Policy 24, 127-176.

Baxter, M. and King, R. (1999), "Measuring business cycles: Approximate band-pass filters for economic time series," Review of Economics and Statistics 81, 575-593.

Bergman, M. (2000), "Finnish and Swedish business cycles in a global context," University of Lund, mimeo.

Bergman, M. (2001), “Finanspolitikens roll i en valutaunion,” University of Lund, mimeo.

Bergstrand, Jeffrey (1990), "The Heckscher-Ohlin-Samuelson model, the Linder Hypothesis and the determinants of bilateral intra-industry trade," Economic Journal $100,1216-1229$.

Berry, R.A. and Soligo, R. (1969), "Some welfare effects of international migration," Journal of Political Economy 77, 778-794.

Boeri, T. and Brücker, H. (2000), The impact of eastern enlargement on employment and labour markets in the EU member states, European Integration Consortium 2000, Berlin.

Bonin, H. (2001), "Fiskalische Effekte der Zuwanderung nach Deutschland: Eine Generationenbilanz," IZA Discussion Paper No. 305.

Borjas, G. (1994), "The economics of immigration," Journal of Economic Literature 32, 1667-1717.

Borjas, G. (1995), "The economic benefits from immigration," Journal of Economic Perspectives 9, 3-22.

Commission of the EU, 2002 regular report on Turkey's progress towards accession, http://europa.eu.int/comm/enlargement/report2002/tu_en.pdf. 
Deardorff, A. (1998), "Determinants of bilateral trade: Does gravity work in a neoclassical world?," in J.A. Frankel (ed.), The regionalization of the world economy (Chicago: The University of Chicago Press).

Evenett, S.J. and Keller, W. (2002), "On theories explaining the success of the gravity equation," Journal of Political Economy, forthcoming.

Feenstra, R.C., Markusen, J.A. and Rose, A.K. (1999), Using the gravity equation to differentiate among alternative theories of trade," manuscript.

Frenkel, J. and Rose, A. (1998), “The endogeneity of the optimum currency area criterion," Economic Journal 108, 1009-1025

Friedberg, R.M. and Hunt, J. (1995), "The impact of immigrants on host country wages, employment and growth," Journal of Economic Perspectives 9, 23-44.

Ghatak, S., Levine, P. and Wheatley Price, S. (1996), "Migration theories and evidence: an assessment," Journal of Economic Surveys, 159-198.

Haisken-De New, J. and Zimmerman, K.F. (1996), "Wage and mobility effects of trade and migration," CEPR Discussion Paper No. 1318.

Harris, J. and Todaro, M. (1970), "Migration, unemployment and development: a twosector analysis," American Economic Review, 126-177.

Helpman, E. (1998), The structure of foreign trade," NBER Working Paper No. 6752.

Kalaycioglu, E. (2002), "Turkey's choice: the road away from the European Union?", in B. Dunér (ed.), Turkey: the road ahead? (Stockholm: The Swedish Institute for International Affairs), manuscript.

Krueger, A. (1973)," The political economy of the rent-seeking society," American Economic Review 64, 291-303.

Lumsdaine, R. and Prasad, E. (1999), "Identifying the common component in international economic fluctuations: A new approach,” IMF Working Paper 99/154.

Müftüler-Bac, M. (19998), "The never-ending story: Turkey and the European Union”, Middle Eastern Studies 34, 240-258.

OECD (2000), Agricultural policies in the OECD countries, monitoring and evaluation 2000 (OECD: Paris).

OECD (2001), Agricultural policies in the OECD countries, monitoring and evaluation 2001 (OECD: Paris). 
Önis, Z. (1995), “Turkey in the post-cold war era: in search of identity”, Middle East Journal 49, 48-68.

Önis, Z. and Riedel, J. (1993), Economic crisis and long term growth in Turkey (Washington: The World Bank).

Sak, G. (2000), "Characteristics fo the fund experience in Turkey: Budgetary funds, extra budgetary funds and other fund-like arrangements," Ankara University, mimeo.

Senatalar, B. (2002), "Public sector reform and combating corruption," in B. Dunér (ed.), Turkey: the road ahead (Stockholm: The Swedish Institute of International Affairs).

Storesletten, K. (2000), "Sustaining fiscal policy through immigration," Journal of Political Economy 108, 300-323.

Stråth, B. (1999), "Europe as a discourse," in B. Stråth (ed.), Europe and the other and Europe as the other (Brussels: P.I.E. - Peter Lang).

UNCTAD, World investment report 2002 (Geneva: UNCTAD).

Winter-Ebner, R. and Zimmerman, K.F. (1998), "East-West trade and migration: the Austro-German case," IZA Discussion Paper No. 2.

Zimmerman, K.F. (1994), "European migration: push and pull," in Proceedings volume of the World Bank Annual Conference on Development Economics, supplement to the World Economic Review and the World Bank Research Observer.

Zimmerman, K.F. (1995), "Tackling the European migration problem," Journal of Economic Perspectives 9, 45-62. 


\title{
CESifo Working Paper Series
}

\author{
(for full list see www.cesifo.de)
}

827 Geir B. Asheim, Green National Accounting for Welfare and Sustainability: A Taxonomy of Assumptions and Results, December 2002

828 Andrea Gebauer, Chang Woon Nam, and Rüdiger Parsche, Lessons of the 1999 Abolition of Intra-EU Duty Free Sales for Eastern European EU Candidates, December 2002

829 Giacomo Corneo, Work and Television, December 2002

830 Vivek H. Dehejia and Yiagadeesen Samy, Trade and Labour Standards - Theory, New Empirical Evidence, and Policy Implications, December 2002

831 Geir B. Asheim and Wolfgang Buchholz, A General Approach to Welfare Measurement through National Income Accounting, December 2002

832 Aaron Tornell and Frank Westermann, The Credit Channel in Middle Income Countries, January 2003

833 Gebhard Flaig, Time Series Properties of the German Monthly Production Index, January 2003

834 Campbell Leith and Jim Malley, Estimated Open Economy New Keynesian Phillips Curves for the G7, January 2003

835 Burkhard Heer and Bernd Süssmuth, Inflation and Wealth Distribution, January 2003

836 Erkki Koskela and Leopold von Thadden, Optimal Factor Taxation under Wage Bargaining - A Dynamic Perspective, January 2003

837 Carola Grün and Stephan Klasen, Growth, Income Distribution, and Well-Being: Comparisons across Space and Time, January 2003

838 Robert S. Chirinko and Ulf von Kalckreuth, On the German Monetary Transmission Mechanism: Interest Rate and Credit Channels for Investment Spending, January 2003

839 Sascha O. Becker, Andrea Ichino, and Giovanni Peri, How Large is the "Brain Drain" from Italy?", January 2003

840 Albert Berry and John Serieux, All About the Giants: Probing the Influences on Growth and Income Inequality at the End of the $20^{\text {th }}$ Century, January 2003

841 Robert Fenge and Martin Werding, Ageing and the Tax Implied in Public Pension Schemes: Simulations for Selected OECD Countries, January 2003 
842 Robert Fenge and Martin Werding, Ageing and Fiscal Imbalances Across Generations: Concepts of Measurement, January 2003

843 Giovanni Andrea Cornia, The Impact of Liberalisation and Globalisation on Income Inequality in Developing and Transitional Economies, January 2003

844 Peter Fredriksson and Per Johansson, Program Evaluation and Random Program Starts, January 2003

845 Bernd Hayo and Matthias Wrede, Fiscal Equalisation: Principles and an Application to the European Union, January 2003

846 Syed M. Ahsan and Jaideep Oberoi, Inequality, Well-being and Institutions in Latin America and the Caribbean, January 2003

847 Chang Woon Nam and Doina Maria Radulescu, The Role of Tax Depreciation for Investment Decisions: A Comparison of European Transition Countries, January 2003

848 V. Bhaskar and Steinar Holden, Wage Differentiation via Subsidised General Training, January 2003

849 Paloma Lopez-Garcia, Labour Market Performance and Start-up Costs: OECD Evidence, January 2003

850 Christian Keuschnigg and Soren Bo Nielsen, Public Policy for Start-up Entrepreneurship with Venture Capital and Bank Finance, January 2003

851 Yin-Wong Cheung, Menzie D. Chinn, and Eiji Fujii, China, Hong Kong, and Taiwan: A Quantitative Assessment of Real and Financial Integration, January 2003

852 Gregory D. Hess, The Economic Welfare Cost of Conflict: An Empirical Assessment, February 2003

853 Douglas J. Cumming and Jeffrey G. MacIntosh, Comparative Venture Capital Governance. Private versus Labour Sponsored Venture Capital Funds, February 2003

854 Eckhard Janeba and John Douglas Wilson, Decentralization and International Tax Competition, February 2003

855 Tapio Palokangas, Capital Accumulation and Employment Cycles in a Model of Creative Destruction, February 2003

856 Brendan Walsh, When Unemployment Disappears: Ireland in the 1990s, February 2003

857 Luis H. R. Alvarez and Erkki Koskela, A General Approach to the Stochastic Rotation Problem with Amenity Valuation, February 2003

858 Christian Schultz, Strategic Campaigns and Redistributive Politics, February 2003

859 Ernst Fehr and Joseph Henrich, Is Strong Reciprocity a Maladaptation? On the Evolutionary Foundations of Human Altruism, February 2003 
860 Haizhou Huang, Dalia Marin, and Chenggang Xu, Financial Crisis, Economic Recovery and Banking Development in Former Soviet Union Economies, February 2003

861 Pedro Cardoso and Bernard M.S. van Praag, How Sustainable Are Old-age Pensions in a Shrinking Population with Endogenous Labour Supply?, February 2003

862 Volker Meier, Efficient Transfer of Aging Provisions in Private Health Insurance, February 2003

863 Edward Castronova, Theory of the Avatar, February 2003

864 Robert S. Chirinko, Hans van Ees, Harry Garretsen, and Elmer Sterken, Investor Protections and Concentrated Ownership: Assessing Corporate Control Mechanisms in the Netherlands, February 2003

865 Bernard M.S. van Praag and Pedro Cardoso, The Mix Between Pay-as-you-go and Funded Pensions and what Demography has to do with it, February 2003

866 Ernst Fehr, Urs Fischbacher, Bernhard von Rosenbladt, Jürgen Schupp, and Gert G. Wagner, A Nation-Wide Laboratory. Examining Trust and Trustworthiness by Integrating Behavioral Experiments into Representative Survey, February 2003

867 Frank Heinemann, The Inflationary Impact of Wage Indexation, February 2003

868 Eytan Sheshinski, Bounded Rationality and Socially Optimal Limits on Choice in a Self-Selection Model, February 2003

869 M. Hashem Pesaran, Estimation and Inference in Large Heterogenous Panels with Cross Section Dependence, February 2003

870 Luis H. R. Alvarez and Erkki Koskela, On the Tree-Cutting Problem under Interest Rate and Forest Value Uncertainty, February 2003

871 Norbert Berthold and Rainer Fehn, Unemployment in Germany: Reasons and Remedies, February 2003

872 Clemens Fuest, Bernd Huber, and Philipp Tilleßen, Tax Policy and Entrepreneurship in the Presence of Asymmetric Information in Capital Markets, February 2003

873 Eytan Sheshinski, Optimum and Risk-Class Pricing of Annuities, February 2003

874 Willi Leibfritz, Paul O'Brien and Jean-Christophe Dumont, Effects of Immigration on Labour Markets and Government Budgets - An Overview, February 2003

875 M. Hashem Pesaran and Allan Timmermann, How Costly is it to Ignore Breaks when Forecasting the Direction of a Time Series?, February 2003

876 Thorvaldur Gylfason and Gylfi Zoega, Education, Social Equality and Economic Growth: A View of the Landscape, February 2003 
877 Robin Boadway and Jean-François Tremblay, Public Economics and Startup Entrepreneurs, February 2003

878 Erkki Koskela and Roope Uusitalo, The Un-Intended Convergence: How the Finnish Unemployment Reached the European Level, February 2003

879 Robert Fenge and Volker Meier, Pensions and Fertility Incentives, February 2003

880 Eytan Sheshinski, Note on Income Taxation and Occupational Choice, February 2003

881 A B Atkinson, Income Inequality in OECD Countries: Data and Explanations, February 2003

882 Thomas Gehrig and Rune Stenbacka, Venture Cycles: Theory and Evidence, February 2003

883 Ralf Becker and Thomas Hellmann, The Genesis of Venture Capital - Lessons from the German Experience, March 2003

884 Eytan Sheshinski, Note on the Optimum Pricing of Annuities, March 2003

885 Paul De Grauwe and Magdalena Polan, Globalisation and Social Spending, March 2003

886 F. van der Ploeg, Do Social Policies Harm Employment and Growth?, March 2003

887 Mirjam van Praag, Initial Capital Constraints Hinder Entrepreneurial Venture Performance: An empirical analysis, March 2003

888 Bernard Steunenberg, Coordinating Sectoral Policymaking: Searching for Countervailing Mechanisms in the EU Legislative Process, March 2003

889 Eytan Sheshinski, Optimum Delayed Retirement Credit, March 2003

890 Frederick van der Ploeg, Rolling Back the Public Sector - Differential effects on employment, investment and growth, March 2003

891 Paul De Grauwe and Marc-Alexandre Sénégas, Monetary Policy in EMU when the Transmission is Asymmetric and Uncertain, March 2003

892 Steffen Huck and Kai A. Konrad, Strategic Trade Policy and the Home Bias in Firm Ownership Structure, March 2003

893 Harry Flam, Turkey and the EU: Politics and Economics of Accession, March 2003 